\title{
13. STABLE ISOTOPE RATIOS OF INTERSTITIAL FLUIDS FROM THE NORTHERN BARBADOS ACCRETIONARY PRISM, ODP LEG 110
}

\author{
P. Vrolijk, ${ }^{2,6}$ S. R. Chambers, ${ }^{3}$ J. M. Gieskes, ${ }^{4}$ and J. R. O’Neil ${ }^{5}$
}

\begin{abstract}
$\delta^{18} \mathrm{O}$ values of pore waters from the northern Barbados accretionary prism range from -0.3 to $-3.6 \%$ and reflect pervasive reaction of volcanic ash to form smectite within the sedimentary sequence and continued low temperature alteration of basalt in the underlying ocean crust with the overprint of diffusive exchange between water in the sediment pores and the open ocean. $\delta \mathrm{D}$ values of pore waters in sediments sampled seaward of the deformation front drop from $+5 \%$ at the sediment surface to $-6 \%$ at the deepest levels sampled. These changes may also be related to alteration processes but remain largely enigmatic. Sediment deformation caused by impingement of the Caribbean plate on the Atlantic plate has instigated migration of chemically and isotopically distinct fluid along faults and coarse-grained sedimentary beds; $\delta^{18} \mathrm{O}$ values of pore waters are also locally affected by thrust stacking which increases diffusive pathlengths and possibly modifies diagenetic reaction rates in Pleistocene sediments. Migrating fluids are distinguished by anomalous $\delta^{18} \mathrm{O}$ values that are as much as $1 \%$ higher than those of surrounding fluids. Uncertainties in hydrogen isotope fractionation resulting from processes occurring under these conditions hinder identification of the hydrogen isotope composition of expelled fluid. Stable isotope analyses of pore waters help constrain the fluid migration history of the accretionary prism by limiting the source of fluids, the paths along which fluid flows, and the timing of faulting and subsequent fluid flow.
\end{abstract}

\section{INTRODUCTION}

Fluid flow from subduction zones is an integral part of the global water cycle and may be important in balancing the flux of solids and heat in the Earth. To assess the importance of fluid flow on various global budgets, direct measurements of the amount and composition of expelled fluids must be made in a variety of subduction zone environments, including fast and slow convergent zones, sediment-rich and sediment-poor zones, and predominantly coarse-grained and fine-grained environments. The Northern Barbados Accretionary Complex (ODP Leg 110) represents a slowly converging subduction zone with abundant, fine-grained hemipelagic sediments.

Pore water geochemistry can directly define paths of fluid flow; this was a first-order goal of the geochemistry program in the Northern Barbados subduction zone (Fig. 1). Distinguishing the geometry of the fluid flow pathways (diffuse or channelized) is required to determine the volume of fluid transported, the distance fluid travels, and the rate at which fluid migrates. Analyses of pore water geochemistry also provide information on the chemistry of fluids returning to the oceans.

Interpretations of geochemical analyses of pore waters and associated data from the Barbados accretionary prism on DSDP Leg 78A (Fig. 1) precluded significant upward advection of pore waters (Gieskes et al., 1984a), but temperature measurements suggested that sediments around active fault zones were warmer than expected (Davis and Hussong, 1984). The most likely explanation of these phenomena is lateral fluid transport along faults.

\footnotetext{
${ }^{1}$ Moore, J. C., Mascle, A., et al., 1990. Proc. ODP, Sci. Results, 110: College Station, TX (Ocean Drilling Program).

2 Department of Earth Sciences, University of Cambridge, Cambridge CB2 3EQ United Kingdom.

3 Department of Geology, Stanford University, Stanford, CA 94305.

${ }^{4}$ Scripps Institution of Oceanography University of California, La Jolla, CA 92093.

${ }_{5}^{5}$ Department of Geological Sciences, University of Michigan Ann Arbor, MI 48109-1063.

${ }^{6}$ Exxon Production Research Co., P.O. Box 2189, Houston, TX 77252-2189.
}

The first goal of this study is to evaluate measurements of oxygen and hydrogen isotope ratios of pore waters in tectonically undisturbed sediments in terms of models of pore water evolution in deep marine sediments. This framework of data and models is then contrasted against results from within the accretionary prism. In addition, conceptual models of tectonically-induced pore water evolution will be developed. Diffusion plays an important role throughout, modifying diageneticallyand tectonically-driven changes in the isotopic composition of pore waters.

\section{Background Effects}

Oxygen and hydrogen isotope ratios of interstitial waters in undeformed sediments may be either (1) inherited from ocean water or (2) derived from diagenetic reactions in the sediment or underlying basement. Over a long time scale, the oxygen isotope composition of the world's oceans is believed to have remained roughly constant (e.g., Muehlenbachs, 1986). Growth and decline of continental glacial ice masses can cause shifts in the oxygen and hydrogen isotope composition of ocean waters by about 1 and $10 \%$, respectively, but recent evidence from ODP Leg 119 that continental glaciers may have existed since the middle of Late Eocene time (Barron, Larsen, Baldauf et al., 1988) makes it difficult to infer whether glacial cycles have influenced the isotopic composition of pore waters in the Northern Barbados accretionary prism. Short-term glacial fluctuations will leave no record in pore waters of slowly accumulating sediments because the rate of diffusion of mass between sediment pores and ocean waters is fast enough to eliminate the paleo-oceanographic signal (McDuff, 1985).

Based on measurements of calcium and magnesium concentrations as well as ${ }^{18} \mathrm{O} /{ }^{16} \mathrm{O}$ and ${ }^{87} \mathrm{Sr} /{ }^{86} \mathrm{Sr}$ ratios in pore waters recovered during DSDP Leg 78a (Gieskes et al., 1984), the principal diagenetic reactions affecting the isotopic compositions of pore waters are low temperature alteration of volcanic ash in the sediment column to form smectite and continued alteration of the underlying basaltic ocean crust to form smectite (e.g., Lawrence et al., 1975; Perry et al., 1976; Lawrence et al., 1979; Gieskes and Lawrence, 1981; Lawrence and Gieskes, 1981; Mc- 
A

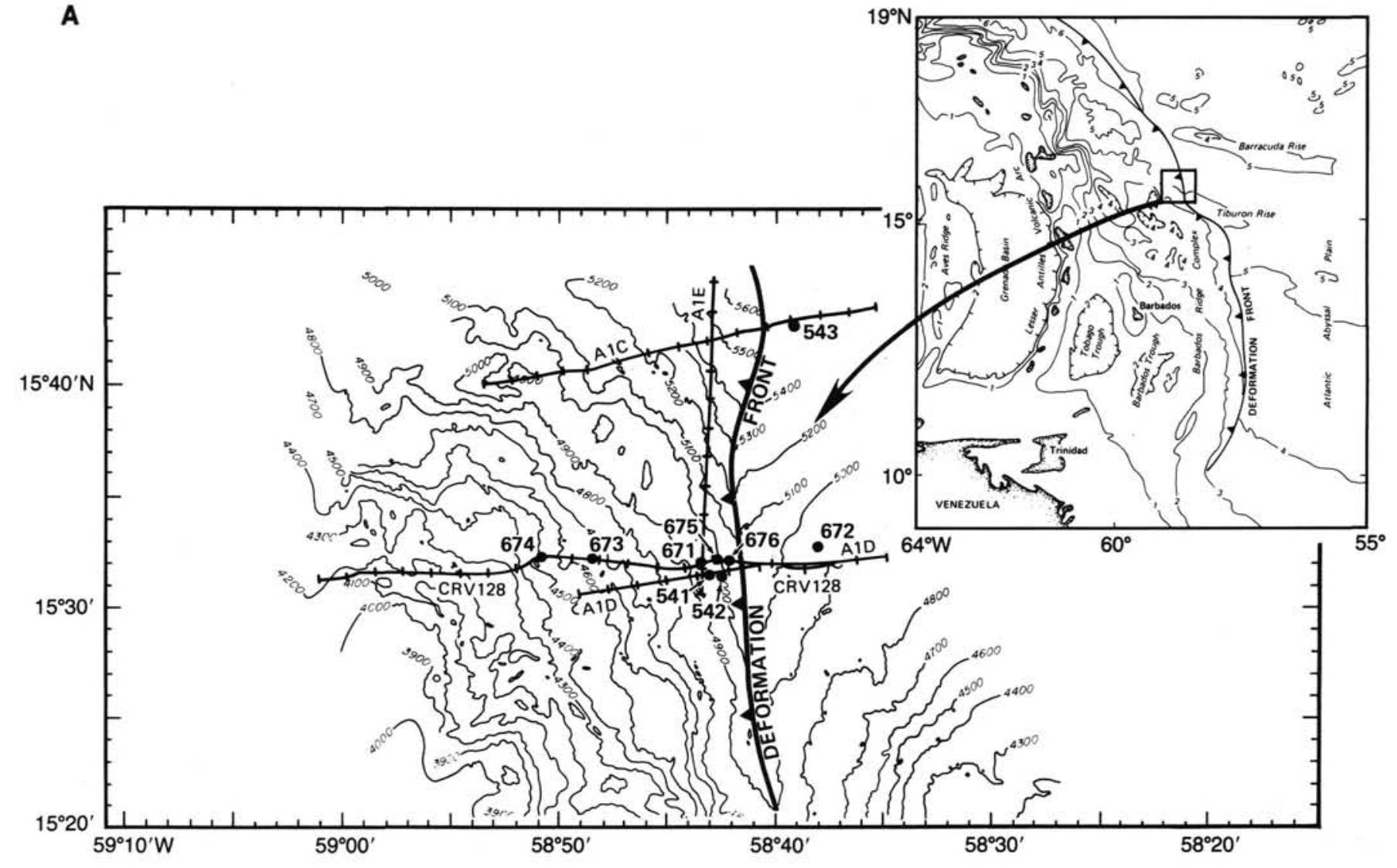

B

West

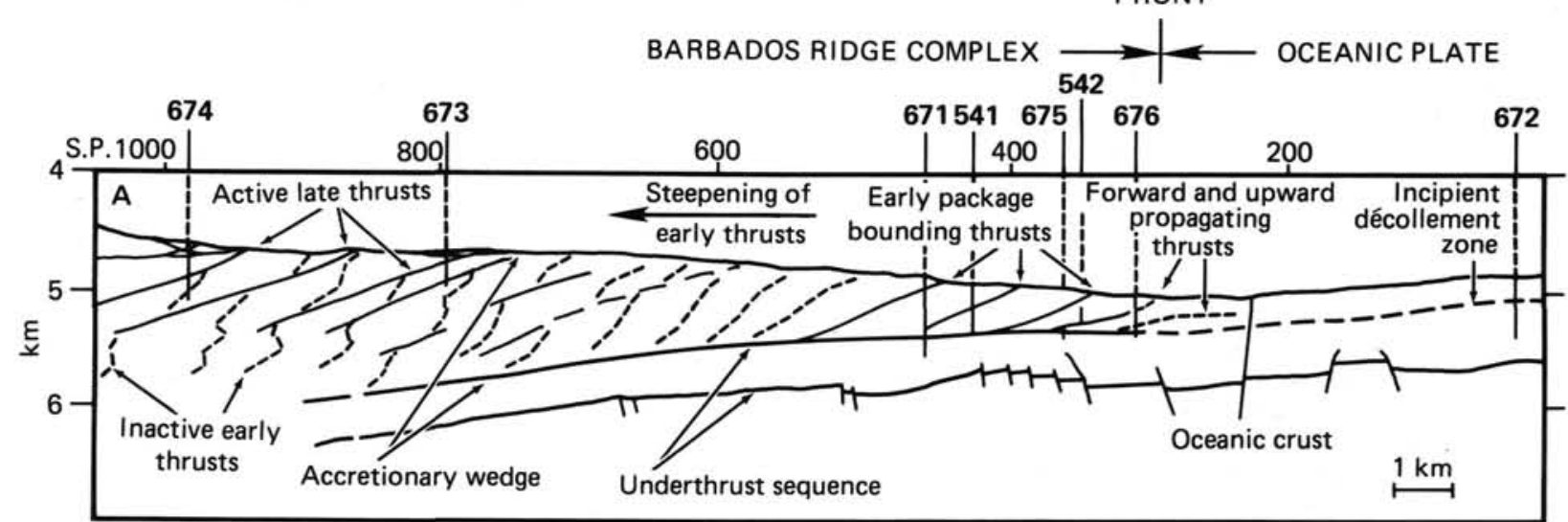

Vertical exaggeration $=2$

Figure 1. (A) Location map of the northern Barbados accretionary prism showing boundary between Caribbean and Atlantic plates (deformation front), locations of nearby seismic reflection profiles, and location of ODP Leg 110 and DSDP Leg 78A drill holes. (B) Cross-section of the northern Barbados accretionary prism. Important structural features and positions of drill sites also shown.

Duff, 1981; Gieskes et al., 1987). The formation of diagenetic smectite has lowered $\delta^{18} \mathrm{O}$ values of pore waters in the northern Barbados accretionary prism by as much as $4 \% 0$ from ocean water values (Gieskes et al., 1984a).

Alteration of volcanic ash should increase $\delta \mathrm{D}$ values of pore waters because the hydroxyl groups in clay minerals incorporate the light isotope of hydrogen relative to water (Savin and Epstein, 1970; Suzuoki and Epstein, 1976; Yeh, 1980; Liu and Epstein, 1984; Cerling et al., 1985). However, measured $\delta \mathrm{D}$ values of pore waters in oceanic sediments generally decrease with an increasing contribution to the pore waters from alteration processes. To explain this, Lawrence and Gieskes (1981) suggested 
that deuterium is preferentially taken up in structural water in the smectite matrix, thereby creating lower $\delta \mathrm{D}$ values in pore waters. This hypothesis remains untested, however, and the degree of deuterium depletion by this mechanism is difficult to predict. Further discussion of the effect of interlayer water in clays on the isotopic composition of pore waters follows in a later section. Possible hydrogen isotope exchange between hydroxyl groups in clay minerals and pore waters will have a negligible effect on $\delta \mathrm{D}$ values of pore waters in a sediment with $50 \%$ porosity.

Lawrence and Taviani (1988) recently suggested that oxidation of mantle-derived methane in the sediment column may significantly lower $\mathrm{D} / \mathrm{H}$ ratios of pore waters. However, if this hypothesis is true, it still remains to be tested if the flux of mantle gases is as important in old ocean basins as in relatively young basins like the Norwegian Sea. Other diagenetic reactions that may alter the isotopic composition of pore waters, such as silica diagenesis (Knauth and Epstein, 1976) and hydrocarbon oxidation (Schoell, 1980), are considered unimportant because of the paucity of reacting materials.

\section{Tectonic Effects}

Based on observations in ancient accretionary complexes (e.g. Vrolijk, 1987) and by analogy with heat-flow models of thrust terranes (e.g. England and Thompson, 1984), tectonic deformation of sediments may result in the alteration of the geochemical and isotopic character of pore waters in two basic ways: (1) faulting can juxtapose blocks and allow mixing of compositionally different pore waters, and (2) exotic fluids may intrude along fault surfaces. These effects are presented schematically in Figure 2. In the first case (Fig. 2B), geochemical signals in pore waters are perturbed from the tectonically undis- turbed state (Fig. 2A) by a thrust fault which places deeper, older sediments on younger ones. Because the chemical composition of pore waters in the older sediments is different from that of the younger sediments, a chemical discontinuity is established along the fault. The isotopic composition of pore fluids on both sides of the fault is altered as diffusion works to destroy the geochemical discontinuity. The physics of this process are analogous to the well-described thermal diffusion processes during nappe emplacement (e.g., England and Thompson, 1984).

A variation of the thrusting model arises from displacement on a bedding-parallel fault which cuts sediments with laterally changing pore-water chemistries (Fig. 2C). Once again faulting creates geochemical discontinuities along the fault plane which results in modified geochemical signals on both sides of the fault as diffusion of materials takes place.

Faults may also act as conduits for fluid flow (Fig. 2D). If fluid flow is rapid enough, it may create perturbations in geochemical profiles (e.g. Kulm et al., 1986; Boulegue et al., 1987; Vrolijk, 1987) and temperature profiles (e.g. Davis and Hussong, 1984; Vrolijk et al., 1988; Fisher and Hounslow, this volume). If fluid flow is active along faults, then the change in oxygen and hydrogen isotope ratios can serve as a means of tracing the source of the fluids and help constrain the fluid flow history.

\section{ANALYTICAL TECHNIQUES}

Water samples were taken for isotopic analysis by squeezing mud samples using conventional techniques (Manheim and Sayles, 1974). An aliquot of each total sample was sealed in glass vials for shore-based analysis. At Site 672, three samples of pore waters were retrieved with an in situ sampler, and in the two samples apparently uncontaminated by seawater (I. S. 1 \& 2; contamination degree defined by major element

(B)

(A)

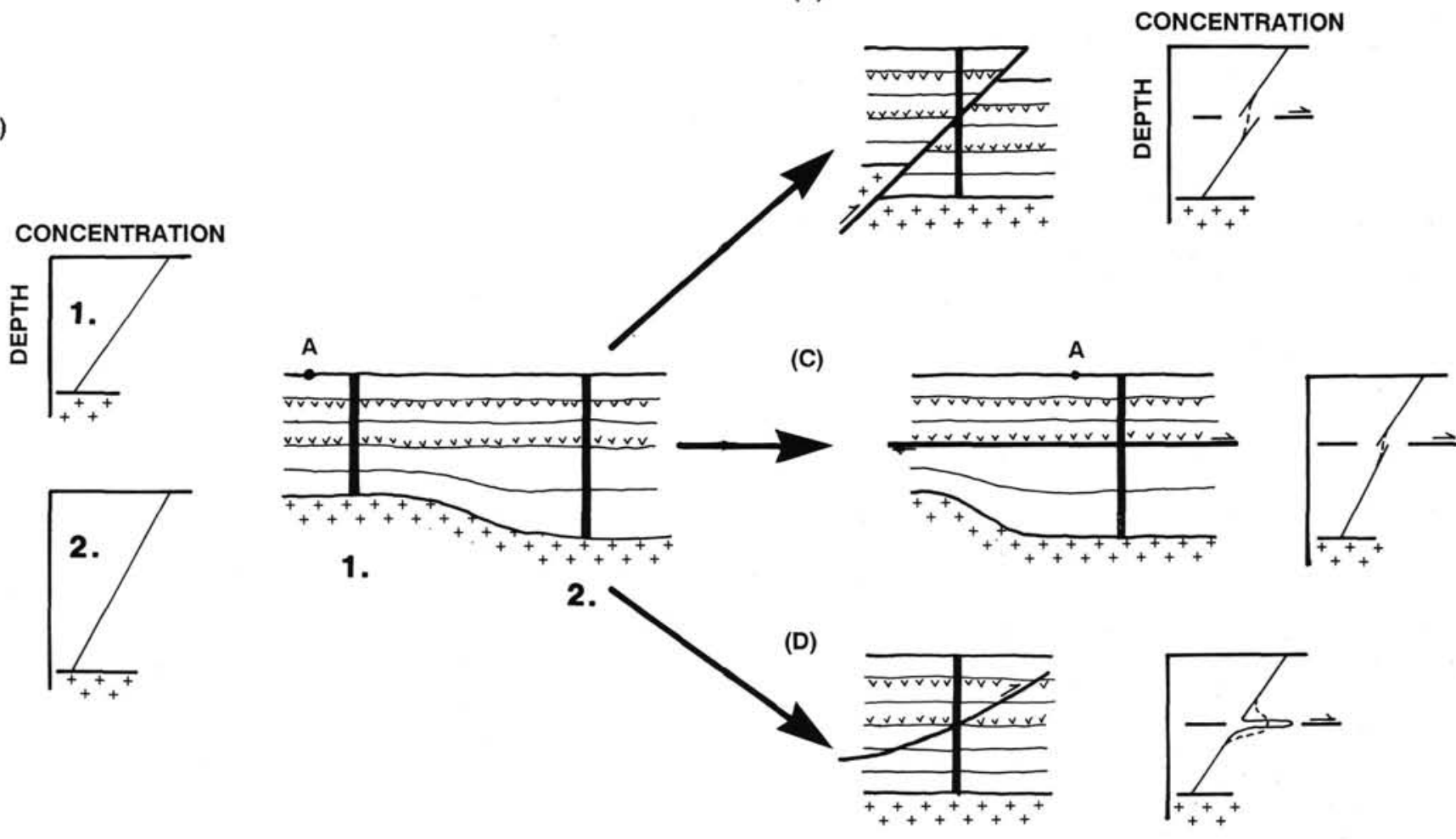

Figure 2. Conceptual effects of deformation on pore water geochemistry. (A) Two examples of steady state, conservative element concentration profiles in a tectonically undisturbed sedimentary section. (B) Thrust stacking of sediments leading to repetition of pore water geochemical signatures. Dashed lines indicate concentration gradient smoothed by diffusion. (C) Bedding-parallel faulting of sediments with laterally changing concentration gradients leads to a discontinuity in values across the fault and a change in slope of gradient. (D) Concentration gradient locally offset by intrusion of chemically distinct fluid, causing a bulge in the concentration gradient. 
and nutrient chemistry of pore waters), $\delta^{18} \mathrm{O}$ and $\delta \mathrm{D}$ values are very close to those of surrounding samples obtained by squeezing (Table 1).

Oxygen isotope ratios of pore waters were determined by the conventional $\mathrm{CO}_{2}$ equilibration technique (Epstein and Mayeda, 1953) modified by initial evacuation of air through teflon capillaries (Roether, 1970). The method was tested and standardized by analysis of four water standards. Analytical precision was further improved by using a $\mathrm{CO}_{2}$ gas with an isotopic composition close to equilibrium with seawater at $25^{\circ} \mathrm{C}$. Thus any errors introduced by incomplete equilibration were negligible. Analyses of two individual aliquots of single samples generally agree to better than $0.1 \%$; an average of eight standard deviations, calculated from eight replicate analyses of individual samples sealed in separate ampules, is $0.09 \%$.

$\delta \mathrm{D}$ values of pore waters were determined by reduction of $4 \cdot 10^{-3} \mathrm{~cm}^{3}$ of water with hot zinc (Friedman, 1953; Coleman et al., 1982). Each pore-water sample was analyzed at least twice, and analytical reproducibility was consistently better than $\pm 1 \%$. Both $\delta^{18} \mathrm{O}$ and $\delta \mathrm{D}$ values in Table 1 are reported relative to SMOW (Standard Mean Ocean Water).

\section{RESULTS}

\section{"Undeformed" Reference Site}

Site 672 was drilled to document the biostratigraphic, lithostratigraphic, structural, and geochemical characteristics of a tectonically undisturbed section. Unfortunately, this site contains two mildly deformed horizons, both of which contain geochemical anomalies, indicating the seaward propagation of deformation and subsequent fluid flow. The older (early Miocene) deformed zone is structurally and geochemically more significant because low-angle shear zones with small displacements were observed in the same stratigraphic position in which the décollement zone is developed at Site 671 (Moore, Mascle et al., 1988 ), and pore waters become depleted in chloride and enriched in methane (pp. 227-231, Mascle, Moore et al., 1988). This geochemical signature mimics the anomalies observed in the décollement zone at Site 671. Similar geochemical anomalies are observed in Oligocene and Eocene silty to sandy beds. In both instances fluid migration from beneath the accretionary prism is interpreted as the cause of the geochemical anomalies (p. 234, Mascle, Moore et al., 1988). Notwithstanding the structural and geochemical data from Site 672, the measured oxygen and hydrogen isotope ratios constitute a type of reference against which results from the more tectonized sites of Leg 110 can be compared; at worst this comparison will lead to an underestimation of the effect of deformation on the fluid history.

Oxygen and hydrogen isotope ratios decrease regularly with depth (Fig. 3). Scatter in the data between 220 and 460 mbsf is related to the occurrence of coarser grained beds which allow expulsion of ${ }^{18} \mathrm{O}$-enriched and possibly D-enriched fluids from beneath the accretionary prism; chlorinities are also scattered. Data that more clearly indicate the isotopic composition of expelled fluids will be presented in a later section.

Reaction of volcanic ash in sediment and basalt in ocean crust to form smectite produces a coupled response in calcium and magnesium concentrations with $\delta^{18} \mathrm{O}$ values of pore waters (Lawrence and Gieskes, 1981; Gieskes and Lawrence, 1981). $\Delta \delta^{18} \mathrm{O}: \Delta \mathrm{Ca}$ ratios (Fig. 3B) fall along a correlation line derived empirically by Lawrence and Gieskes (1981) while points that lie significantly off this line represent samples that were taken near coarse-grained beds and which are consistently enriched in ${ }^{18} \mathrm{O}$ and depleted in chloride. $\Delta \delta^{18} \mathrm{O}: \Delta \mathrm{Mg}$ ratios (Fig. $3 \mathrm{C}$ ) increase from the upper $200 \mathrm{~m}$ of Site 672 where volcanic ash is most common to deeper parts of the hole. The higher $\Delta \delta^{18} \mathrm{O}: \Delta \mathrm{Mg}$ ratios below 200 mbsf (meters below seafloor) are produced by alteration reactions in the underlying basalt and projection of this trend to the basalt/sediment contact suggests that pore waters in basalt contain no magnesium. The shift in $\Delta \delta^{18} \mathrm{O}: \Delta \mathrm{Mg}$ ratios
Table 1. Pore-water stable isotope ratios.

\begin{tabular}{|c|c|c|c|c|}
\hline $\begin{array}{c}\text { Core- } \\
\text { section }\end{array}$ & Depth & $\delta^{18} \mathrm{O}$ & $\delta \mathrm{D}$ & Age \\
\hline \multicolumn{5}{|l|}{ 110-671B- } \\
\hline $1-3$ & 4.5 & -0.5 & & E. Pleistocene \\
\hline $2-5$ & 16 & -0.6 & -2 & E. Pleistocene \\
\hline $3-4$ & 22 & -0.7 & +2 & E. Pleistocene \\
\hline $4-5$ & 33 & -0.8 & & L. Pliocene \\
\hline $6-4$ & 50.5 & -0.9 & +1 & L. Pliocene \\
\hline $8-4$ & 68.5 & -1.2 & & L. Pliocene \\
\hline $10-3$ & 86 & -1.7 & -1 & E. Pliocene \\
\hline $13-3$ & 113 & -1.8 & -2 & L. Miocene \\
\hline $15-1$ & 127 & -1.8 & -5 & E. Pleistocene \\
\hline 19-1 & 171 & -1.7 & +1 & E. Pleistocene \\
\hline $22-5$ & 200 & -1.9 & & E. Pleistocene \\
\hline $25-4$ & 230 & -1.7 & -5 & L. Pliocene \\
\hline $28-5$ & 260 & -2.1 & & L. Pliocene \\
\hline $31-1$ & 290 & -1.9 & -1 & E. Pliocene \\
\hline $33-2$ & 310 & -1.6 & -4 & E. Pliocene \\
\hline $34-3$ & 320 & -2.2 & & E. Pliocene \\
\hline $37-2$ & 348 & -1.8 & -1 & L. Miocene \\
\hline $40-3$ & 368 & -2.3 & -5 & L. Miocene \\
\hline $41-4$ & 380 & -1.8 & -4 & L. Miocene \\
\hline $43-3$ & 397 & -1.5 & +3 & L. Miocene \\
\hline $46-3$ & 420 & -2.6 & -4 & L. Miocene \\
\hline $49-2$ & 450 & -1.9 & +1 & E./M. Miocene(?) \\
\hline $52-2$ & 477 & -2.0 & -3 & E./M. Miocene(?) \\
\hline $55-5$ & 508 & -2.4 & +0 & E./M. Miocene \\
\hline $56-2$ & 516 & -1.7 & -6 & E./M. Miocene(?) \\
\hline $58-6$ & 535 & -2.6 & +1 & L. Oligocene \\
\hline $63-5$ & 580 & -3.0 & -5 & E. Oligocene \\
\hline $65-5$ & 600 & & -5 & E. Oligocene \\
\hline $67-5$ & 620 & -3.4 & -1 & E. Oligocene \\
\hline $70-4$ & 650 & -3.4 & +4 & E. Oligocene \\
\hline $73-5$ & 675 & -3.6 & -8 & E. Oligocene \\
\hline \multicolumn{5}{|l|}{$110-671 \mathrm{C}-$} \\
\hline $1-4$ & 502 & -2.4 & -6 & E. Miocene \\
\hline $1-5$ & 503 & -2.4 & -6 & E. Miocene \\
\hline $2-1$ & 507 & -1.8 & -3 & E. Miocene \\
\hline $2-4$ & 511 & -1.2 & -1 & E. Miocene \\
\hline $2-\mathrm{CC}$ & 514.5 & -2.6 & -6 & E. Miocene \\
\hline \multicolumn{5}{|l|}{$110-672 \mathrm{~A}-$} \\
\hline $2-6$ & 12 & -0.3 & +5 & E. Pleistocene \\
\hline $3-4$ & 18 & -0.5 & +5 & E. Pleistocene \\
\hline $4-5$ & 29 & -0.3 & +3 & E. Pleistocene \\
\hline $5-5$ & 38.5 & -0.7 & +3 & L. Pliocene \\
\hline I.S. 1 & 40 & -0.6 & +1 & L. Pliocene \\
\hline $7-5$ & 57.5 & -0.8 & +5 & L. Pliocene \\
\hline $9-5$ & 76 & -1.1 & +1 & L. Pliocene \\
\hline I.S. 2 & 89 & -0.9 & +3 & L. Pliocene \\
\hline $12-5$ & 105 & -1.3 & +0 & E. Pliocene \\
\hline $15-3$ & 130 & -1.5 & +1 & L. Miocene \\
\hline I.S. 3 & 132 & $(-0.8)$ & $(+2)$ & L. Miocene \\
\hline $18-3$ & 158 & -1.5 & -2 & L. Miocene \\
\hline $21-2$ & 185 & -2.0 & -3 & E. Miocene \\
\hline $24-5$ & 216 & -2.4 & -3 & L. Oligocene \\
\hline $27-5$ & 245 & -2.4 & -0 & L. Oligocene \\
\hline $30-5$ & 274 & -2.8 & -4 & E. Oligocene \\
\hline $32-4$ & 290 & -2.7 & -2 & E. Oligocene \\
\hline 34.4 & 309 & & -4 & E. Oligocene \\
\hline $36-4$ & 327 & -2.7 & -7 & E. Oligocene \\
\hline $38-5$ & 346 & -3.3 & -1 & L. Eocene/E. Oligocene \\
\hline $39-2$ & 352 & -3.3 & -5 & L. Eocene \\
\hline 43-4 & 395 & -3.5 & -5 & M. Eocene \\
\hline $46-1$ & 425 & -3.5 & -9 & M. Eocene \\
\hline $48-3$ & 447 & -2.2 & +2 & M. Eocene \\
\hline $51-2$ & 470 & -3.6 & -6 & M. Eocene \\
\hline $53-4$ & 489 & -3.1 & -5 & E. Eocene \\
\hline
\end{tabular}


Table 1 (continued).

\begin{tabular}{|c|c|c|c|c|}
\hline $\begin{array}{l}\text { Core- } \\
\text { section }\end{array}$ & Depth & $\delta^{18} \mathrm{O}$ & $\delta \mathrm{D}$ & Age \\
\hline \multicolumn{5}{|l|}{ 110-673B- } \\
\hline $\begin{array}{l}1-4 \\
4-5 \\
7-1 \\
12-2 \\
15-5 \\
18-2 \\
25-4 \\
28-5 \\
31-6 \\
35-5\end{array}$ & $\begin{array}{r}6 \\
34 \\
57 \\
105 \\
136 \\
164 \\
230 \\
260 \\
290 \\
318\end{array}$ & $\begin{array}{l}-0.5 \\
-1.1 \\
-1.7 \\
-2.7 \\
-2.6 \\
-2.6 \\
-2.5 \\
-3.0 \\
-2.6\end{array}$ & $\begin{array}{l}-2 \\
+1 \\
-1 \\
-5 \\
-7 \\
-8 \\
-8 \\
-7 \\
-7 \\
-8\end{array}$ & $\begin{array}{l}\text { E. Pleistocene } \\
\text { L. Pliocene } \\
\text { E./M. Miocene(?) } \\
\text { E. Miocene } \\
\text { E. Miocene } \\
\text { E. Miocene } \\
\text { E. Miocene } \\
\text { E. Miocene } \\
\text { E. Miocene } \\
\text { E. Miocene }\end{array}$ \\
\hline \multicolumn{5}{|l|}{$110-674 \mathrm{~A}-$} \\
\hline $\begin{array}{l}1-3 \\
2-6 \\
3-5 \\
4-3 \\
5-4 \\
7-2 \\
9-6 \\
12-3 \\
15-2 \\
18-5 \\
21-3 \\
24-5 \\
27-5 \\
30-3 \\
45-3 \\
48-3\end{array}$ & $\begin{array}{l}4.5 \\
15.5 \\
23.5 \\
30 \\
40.5 \\
57 \\
82 \\
105 \\
132 \\
165 \\
190 \\
220 \\
250 \\
275 \\
421 \\
448\end{array}$ & $\begin{array}{l}-0.5 \\
-0.5 \\
-0.3 \\
-0.6 \\
-1.0 \\
-1.2 \\
-1.5 \\
-1.7 \\
-1.7 \\
-2.3 \\
-2.2 \\
-2.3 \\
-2.0 \\
-1.7 \\
-1.1 \\
-1.2\end{array}$ & $\begin{array}{l}+5 \\
+2 \\
+2 \\
+2 \\
-1 \\
-3 \\
-3 \\
-5 \\
-4 \\
-5 \\
-6 \\
-6 \\
-5 \\
-1 \\
-9 \\
-9\end{array}$ & $\begin{array}{l}\text { E. Pleistocene } \\
\text { E. Pleistocene } \\
\text { E. Pleistocene } \\
\text { E. Pleistocene(?) } \\
\text { E. Pleistocene } \\
\text { L. Pliocene } \\
\text { Miocene(?)* } \\
\text { L. Pliocene } \\
\text { E. \& M. Miocene(?)* } \\
\text { E. \& M. Miocene(?)* } \\
\text { E. \& M. Miocene(?)* } \\
\text { E. \& M. Miocene(?)* } \\
\text { E. \& M. Miocene(?)* } \\
\text { M. Eocene } \\
\text { Oligocene(?)* } \\
\text { Oligocene(?)* }\end{array}$ \\
\hline \multicolumn{5}{|l|}{$110-675 \mathrm{~A}-$} \\
\hline $\begin{array}{l}2-2 \\
3-2 \\
4-3 \\
5-3 \\
6-5 \\
8-4\end{array}$ & $\begin{array}{l}325 \\
334 \\
345 \\
355 \\
366 \\
385\end{array}$ & $\begin{array}{l}-2.8 \\
-1.7 \\
-2.0 \\
-3.1 \\
-2.6\end{array}$ & $\begin{array}{l}-6 \\
-7 \\
-6 \\
-3 \\
-7 \\
-6\end{array}$ & $\begin{array}{l}\text { E./M. Miocene(?) } \\
\text { E./M. Miocene(?) } \\
\text { E./M. Miocene(?) } \\
\text { E./M. Miocene(?) } \\
\text { E. Miocene } \\
\text { E. Miocene }\end{array}$ \\
\hline \multicolumn{5}{|l|}{$110-676 \mathrm{~A}-$} \\
\hline $\begin{array}{l}4-5 \\
15-2 \\
21-3 \\
25-1 \\
30-5 \\
33-5\end{array}$ & $\begin{array}{r}33 \\
133 \\
190 \\
228 \\
275 \\
305\end{array}$ & $\begin{array}{l}-0.9 \\
(+4.5) \\
-2.3 \\
-2.2 \\
-2.3 \\
-2.8\end{array}$ & $\begin{array}{c}-2 \\
(+12) \\
-7 \\
-6 \\
-7\end{array}$ & $\begin{array}{l}\text { E. Pleistocene } \\
\text { E. Pliocene } \\
\text { L. Miocene } \\
\text { L. Miocene } \\
\text { E. Miocene } \\
\text { E. Miocene }\end{array}$ \\
\hline
\end{tabular}

* Based on lithostratigraphy (Mascle, Moore, et al., 1988).

occurring at $200 \mathrm{mbsf}$ also corresponds to a shift in ${ }^{87} \mathrm{Sr} /{ }^{86} \mathrm{Sr}$ ratios of dissolved $\mathrm{Sr}$ in pore waters (Gieskes et al., this volume).

Changes in the hydrogen isotope ratio of pore waters at Site 672 (Fig. 3A) are less easily explained. Both oxygen and hydrogen isotope ratios decrease systematically with depth and some common mechanism may be responsible for the excellent correlation between the two isotopic systems (Fig. 3D), or diffusion may have obliterated variations due to different diagenetic processes. Regardless of the cause of variations in hydrogen isotope ratios with depth, the systematics established at Site 672 can be used on a local, comparative basis to search for areas where tectonism has upset relations between $\delta \mathrm{D}$ and depth and between $\delta^{18} \mathrm{O}$ and $\delta \mathrm{D}$.

Lastly, squeezing water from the sediment samples may have induced membrane effects with associated hydrogen isotope fractionation (Coplen and Hanshaw, 1973). However, the shift of $>10 \%$ in $\delta \mathrm{D}$ values reported here is much larger than the $2.5 \%$ shift observed by Coplen and Hanshaw (1973) in laboratory studies, and Lawrence and Gieskes (1981) similarly dismiss the effect of squeezing on hydrogen isotope ratios.

\section{Accretionary Prism}

On the basis of preliminary structural and geochemical analyses of materials within the accretionary prism (Moore, Mascle, Taylor et al., 1987; Moore, Mascle et al., 1988; Gieskes et al., 1989), stable isotope ratios of pore waters from the accretionary prism are presented in two groups: (1) samples taken from the deformation front (Sites 671, 675, and 676), with results from Site 671 comprising the most comprehensive data, and (2) samples from the mid-slope of the accretionary prism (Sites 673 and 674), where the effects of continuing deformation and fluid evolution are apparent.

\section{Deformation Front}

\section{Site 671-Cross Section of a Subduction Zone}

The principal deformation features observed at Site 671 (Fig. $4 \mathrm{~A}$ ) are imbricate thrust faults at 128,375 , and $455 \mathrm{mbsf}$, the décollement zone, which is the detachment horizon between the Caribbean and subducting Atlantic plates, and dispersed scaly shear zones with no apparent stratigraphic throw (p. 73, Mascle, Moore et al., 1988). Pore waters become progressively more depleted in ${ }^{18} \mathrm{O}$ and $\mathrm{D}$ with depth (Fig. 4A, Table 1), and consideration of $\Delta \delta^{18} \mathrm{O}: \Delta \mathrm{Ca}$ (Fig. 4B) and $\Delta \delta^{18} \mathrm{O}: \Delta \mathrm{Mg}$ (Fig. 4C) ratios suggest that alteration of volcanic ash and basaltic ocean crust continue to be important processes. However, there are significant departures in oxygen and hydrogen isotope ratios from those observed at Site 672 that bear on the presence of deformation features.

Shallow Thrusting: The first disturbance in the profile of oxygen and hydrogen isotope ratios occurs below 128 mbsf where Early Pleistocene sediments, with initial $\delta^{18} \mathrm{O}$ values of pore waters inferred to lie between between 0 and $-1 \%$, were thrust beneath Late Miocene sediments, whose pore waters had $\delta^{18} \mathrm{O}$ values between -1.5 to $-2 \%$ before thrusting (Fig. 4A). Initial values are inferred from results of pore waters in sediments of similar age at Site 672 and from present conditions at Site 671. In contrast to the effects depicted in Figure 2B, the stratigraphy of oxygen isotope ratios has not been repeated. Thrusting has caused the diffusive path between sediment pores and the ocean to increase by at least $128 \mathrm{~m}$ (neglecting tortuosity in the sediment), resulting in greatly reduced diffusive exchange between the Pleistocene section beneath the fault and the ocean. In addition, thrusting has led to a more rapid burial and warming of the early Pleistocene sediments beneath the fault, possibly causing alteration reaction to be accelerated. Alternatively fluid depleted in ${ }^{18} \mathrm{O}$ may have been intruded beneath the fault, but the relatively strong enrichment in calcium and depletion in magnesium precludes this as an important process here.

An additional point is that $\delta^{18} \mathrm{O}$ values of pore waters above the fault appear undisturbed by thrusting, also in contrast to the hypothetical situation presented in Figure 2B. This suggests that either reactions in the lower plate occur so fast relative to diffusion of oxygen isotopes in water that the extreme concentration gradient established by thrusting is quickly eliminated, or that diffusion across the fault is hindered; perhaps both processes are operative.

Distributed Faulting: Between the thrust fault at $128 \mathrm{mbsf}$ and the décollement zone, a great deal of scatter is apparent in the profiles of both oxygen and hydrogen isotope ratios (Fig. 4A). This scatter is striking in light of the the comparatively small degree of scatter in major element profiles, particularly chloride (pp. 92-99, Mascle, Moore et al., 1988), and the regularity of the data above 128 mbsf. Moreover, scatter first becomes apparent in the profiles of oxygen and hydrogen isotope ratios at the point where chloride concentrations begin to drop below seawater concentrations (ca. $200 \mathrm{mbsf}$ ), and the magni- 
A
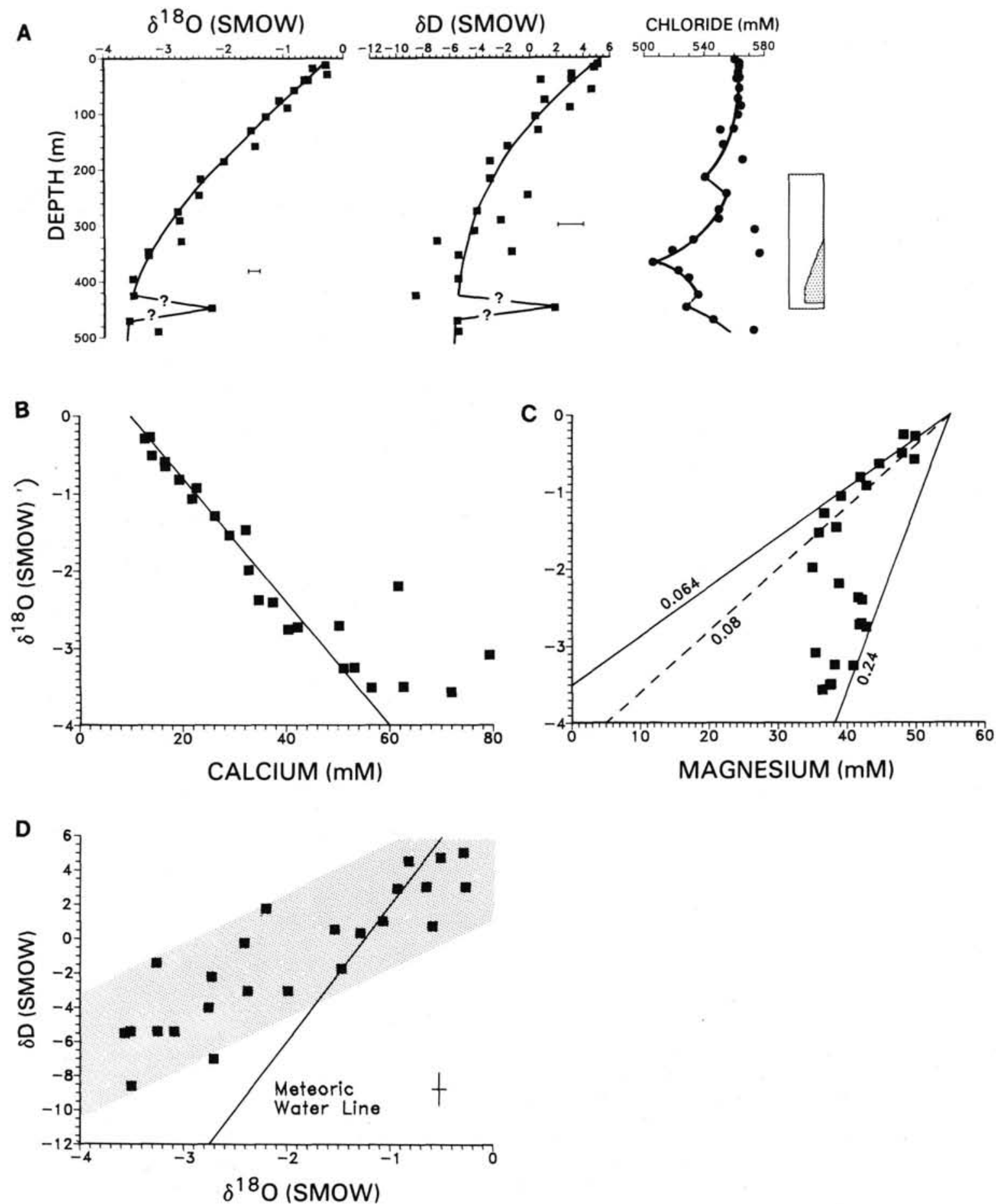

Figure 3. Isotopic results, Site 672. A) Pore water $\delta^{18} \mathrm{O}$ and $\delta \mathrm{D}$ values versus depth. Curves drawn through data points subjectively and represent no mathematical or chemical model. Chloride profile presented for comparison (data from Mascle, Moore et al., 1988). Interval of silty to sandy beds encountered in the Oligocene and Eocene sections and which are interpreted to be hydrologically important are highlighted by abbreviated stratigraphic column (silt $=$ fine stippled pattern, sand $=$ coarse stippled pattern); full stratigraphic columns from Mascle, Moore et al., 1988. Analytical uncertainty indicated by error bars. (B) Correlation of pore water calcium concentrations with $\delta^{18} \mathrm{O}$ values. Line drawn through data has slope $\Delta \delta^{18} \mathrm{O} / \Delta \mathrm{Ca}=-0.08$ permil/mM/L, following compilation of all DSDP pore water data where volcanic ash alteration and ocean crust basalt alteration determine pore water geochemistry (Lawrence and Gieskes, 1981). Ocean water $\mathrm{Ca}=10 \mathrm{mM} / \mathrm{L}, \delta^{18} \mathrm{O}=0$ permil. $(\mathrm{C}) \mathrm{Cor}-$ relation of pore water magnesium concentrations with $\delta^{18} \mathrm{O}$ values. Dashed line indicates $\Delta \delta^{18} \mathrm{O} / \Delta \mathrm{Mg}=0.08 \mathrm{permil} / \mathrm{mM} / \mathrm{L}$, which is equivalent to $\Delta \mathrm{Ca} / \Delta \mathrm{Mg}=-1$. Two solid lines bracket most data, with low slopes $\left(\Delta \delta^{18} \mathrm{O} / \Delta \mathrm{Mg}=0.064 \mathrm{permil} / \mathrm{mM} / \mathrm{L}\right)$ corresponding to data from ash-rich, Pliocene-Pleistocene sections, and high slopes $\left(\Delta \delta^{18} \mathrm{O} / \Delta \mathrm{Mg}=0.24 \mathrm{permil} / \mathrm{mM} / \mathrm{L}\right) \mathrm{corre}-$ sponding to data from ash-poor Oligocene and Eocene sections. Ocean water $\mathrm{Mg}=55 \mathrm{mM} / \mathrm{L}, \delta^{18} \mathrm{O}=0$ permil. Reference lines established in previous two plots will appear in all forthcoming correlation plots. (D) Correlation of pore water oxygen and hydrogen isotope ratios. Meteoric water line is drawn for reference, although it has no inherent significance here. Stippled field covers the range of data and will be reproduced in all forthcoming correlation plots as a further reference. 

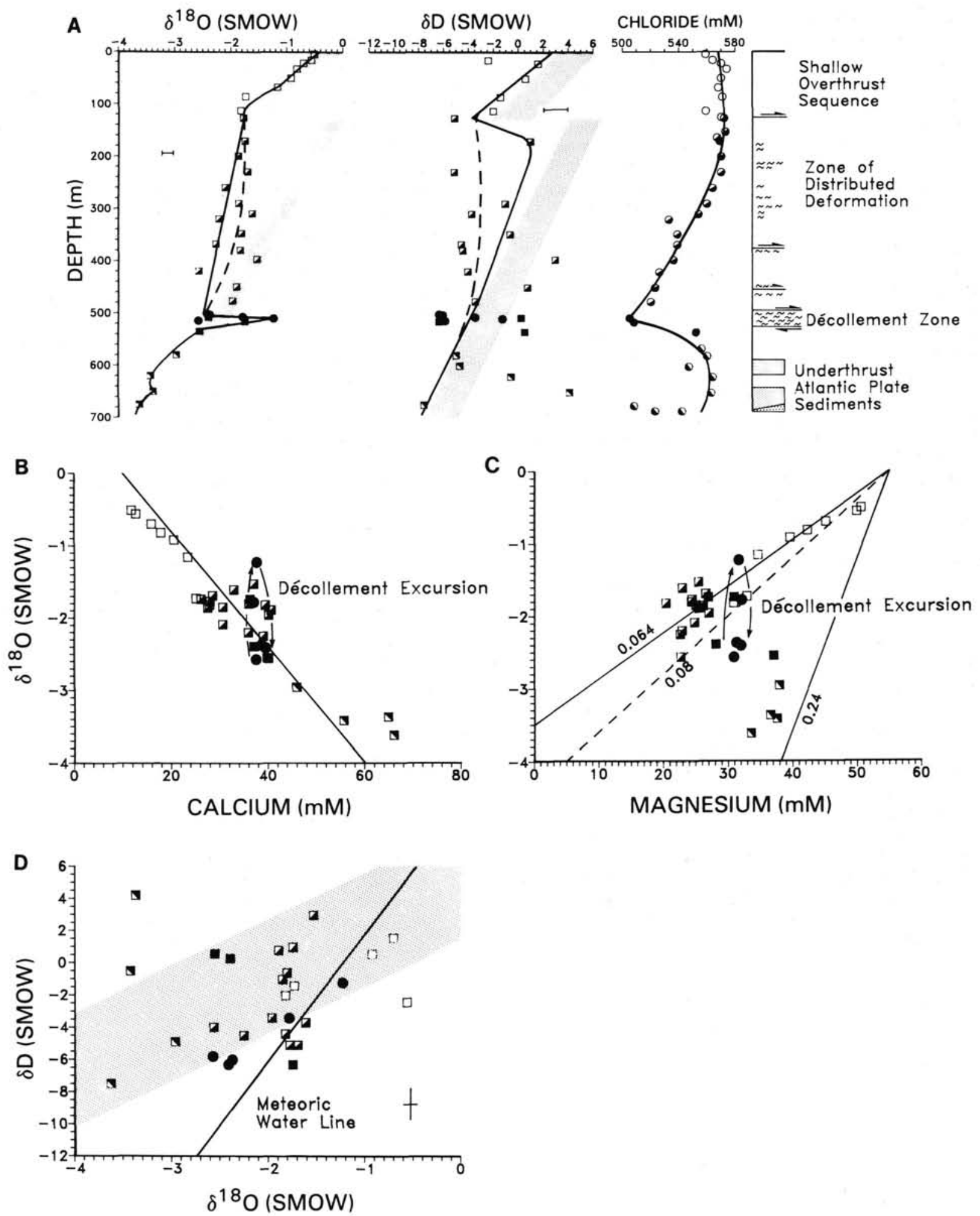

Figure 4. Isotopic results, Site 671. (A) Pore water $\delta^{18} \mathrm{O}$ and $\delta \mathrm{D}$ values versus depth; chloride profile from Mascle, Moore et al. (1988). All conventions as at Site 672 (Fig. 3). Included in these plots are a schematic column of important deformation features. Lines with half arrows indicate thrust faults (longer ones are deemed structurally more significant) and wavy lines indicate zones of scaly muds half arrows indicate thrust faults (longer ones are deemed structuration broken into four main structural domains, discussed in text. Squares represent data from Hole 671B and circles from Hole 671C. Open symbols belong to samples in shallow overthrust sequence, bottom-half diagonally filled symbols represent samples from zone of distributed deformation between shallow thrust fault and décollement zone, filled symbols correspond to samples from décollement zone, and top-half diagonally filled symbols represent samples from underthrust sedimentary sequence. Stippled pattern indicates range of pore water $\delta^{18} \mathrm{O}$ and $\delta \mathrm{D}$ values for sediments of comparable age at Site 672 . (B) Correlation of pore water calcium concentrations with $\delta^{18} \mathrm{O}$ values. (C) Correlation of pore water magnesium concentrations with $\delta^{18} \mathrm{O}$ values. (D) Correlation of pore water oxygen and hydrogen isotope ratios. All conventions and correlations as established at Site 672 (Fig. 3). 
tude of scatter increases as chloride concentrations decrease, culminating in the maximum range in $\delta^{18} \mathrm{O}$ and $\delta \mathrm{D}$ values and lowest chloride concentrations in the décollement zone. Because no cause for heterogeneous, in situ isotopic exchange can be identified in these sediments and because $\mathrm{O}$ - and $\mathrm{H}$-isotopes in water diffuse more rapidly than major elements (Wang et al., 1953; McDuff, 1981), we suggest that the scatter arises from the lateral intrusion of isotopically distinct fluid. Sample contamination is ruled out on the basis that the analytical procedures are routine and because contamination is not reflected in other geochemical systems.

Pore waters in this part of the section with low $\delta^{18} \mathrm{O}$ values are interpreted to be derived from in-situ alteration reactions whereas relatively high $\delta^{18} \mathrm{O}$ values reflect the influence of laterally intruded waters. In-situ reactions which form the abundant diagenetic smectite observed in the Miocene section (Tribble, this volume) are similarly reflected in profiles of calcium and magnesium concentrations (Gieskes et al., this volume).

Décollement Zone: The greatest scatter in the isotopic data occurs in the décollement zone, especially when data from Hole $671 \mathrm{C}$ are included in the analysis (Fig. 5). The lowest $\delta^{18} \mathrm{O}$ values are comparable with $\delta^{18} \mathrm{O}$ values of pore waters in early Miocene sediments at Site 672 , suggesting that the higher $\delta^{18} \mathrm{O}$ values observed reflect intrusion of ${ }^{18} \mathrm{O}$-enriched fluid along the décollement zone. $\Delta \delta^{18} \mathrm{O}: \Delta \mathrm{Ca}$ ratios (Fig. $4 \mathrm{~B}$ ) and $\Delta \delta^{18} \mathrm{O}: \Delta \mathrm{Mg}$ ratios (Fig. 4C) of samples from the décollement zone are displaced toward higher $\delta^{18} \mathrm{O}$ values, which also suggests that waters along the décollement zone are enriched in ${ }^{18} \mathrm{O}$.

The most dramatic shift in isotopic values comes from samples taken in Hole 671C. However, in the Site 671 Geochemistry Report (p. 97, Mascle, Moore et al., 1988), the possibility was raised that all samples from Hole $671 \mathrm{C}$ except $110-671 \mathrm{C}-2 \mathrm{X}-\mathrm{CC}$ may have been contaminated with seawater. However, differences in concentrations of major constituents and in isotopic ratios between individual samples are inconsistent with a large degree of contamination by seawater. Differences in calcium concentration permit seawater to make up only $15 \%$ of the most contaminated water sample, which accounts for at most a $0.4 \%$ shift in its $\delta^{18} \mathrm{O}$ value.

Hydrogen isotope ratios of pore waters from the décollement zone span the range of values measured for waters at Site 672. Results from Hole 671B allow intruded fluids to be both enriched and depleted in deuterium (Table 1), but more detailed analyses from Hole $671 \mathrm{C}$ (Table 1) suggest that samples enriched in ${ }^{18} \mathrm{O}$ are also enriched in deuterium. However, no sys- tematic shift is seen in the isotopic composition of pore waters from values determined at Site 672 (Fig. 4D).

The great changes in $\delta^{18} \mathrm{O}$ and $\delta \mathrm{D}$ values over short vertical distances suggest that fluid intrusion has occurred recently and may be going on at present. Modeling the timing of fluid intrusion is inappropriate at this time because of uncertainties in diffusivities across fault surfaces and because fluid flow is probably two-, and perhaps three-dimensional.

Underthrust Sedimentary Sequence: Magnesium concentrations of pore waters in the underthrust sediments preserve a "fossil" basement signal and appear unaffected by processes occurring within the accretionary prism (pp. 93-95, Mascle, Moore et al., 1988). The $\delta^{18} \mathrm{O}$ values of pore waters beneath the décollement zone similarly decrease regularly with depth, probably reflecting a basement signal. Samples taken around the Oligocene silty/sandy horizons are enriched in ${ }^{18} \mathrm{O}$ and deuterium and depleted in chloride.

\section{Results from Sites 675 and 676}

Site 675 was drilled into the décollement zone just $2 \mathrm{~km}$ arcward of the deformation front, but probably did not completely penetrate it. Oxygen isotope ratios vary by $1.4 \% 0$ over about $30 \mathrm{~m}$ (Fig. 6A), just as was observed in the décollement zone at Site 671 , although hydrogen isotope ratios are fairly constant. The highest $\delta^{18} \mathrm{O}$ values of pore waters occur along a ramping thrust fault above the décollement zone (ca. $340 \mathrm{mbsf}$ ); samples along this fault also contain anomalous chloride and methane concentrations (pp. 493-494, Mascle, Moore et al., 1988), suggesting that fluid flow has recently been concentrated here rather than in the décollement zone in the early Miocene section. In addition, $\Delta \delta^{18} \mathrm{O}: \Delta \mathrm{Ca}$ ratios (Fig. $6 \mathrm{~B}$ ) and $\Delta \delta^{18} \mathrm{O}$ : $\Delta \mathrm{Mg}$ ratios (Fig. $6 \mathrm{C}$ ) reflect the greatest ${ }^{18} \mathrm{O}$ enrichment along this fault. $\delta \mathrm{D}$ values of pore waters from Site 675 are somewhat lower than those in sediments of comparable age at Site 672 (Table 1), but comparison of oxygen and hydrogen isotope ratios (Fig. 6D) suggests that the stable isotope system has not been significantly offset from the relations defined at Site 672 .

At Site $676, \delta^{18} \mathrm{O}$ values of pore waters are lower than those measured in Miocene sediments at Site 672 (Table 1, Fig. 7A), but $\Delta \delta^{18} \mathrm{O}: \Delta \mathrm{Ca}$ (Fig. $7 \mathrm{~B}$ ) and $\Delta \delta^{18} \mathrm{O}: \Delta \mathrm{Mg}$ ratios (Fig. $7 \mathrm{C}$ ) suggest that this may simply be a result of a higher degree of ash alteration, slower diffusion, or higher sedimentation rates. The fact that $\delta \mathrm{D}$ values of pore waters from Site 676 are also lower than those from Site 672 (Table 1), when considered in conjunction with ${ }^{18} \mathrm{O} /{ }^{16} \mathrm{O}$ ratios (Fig. 7D), suggests that there is no sig-
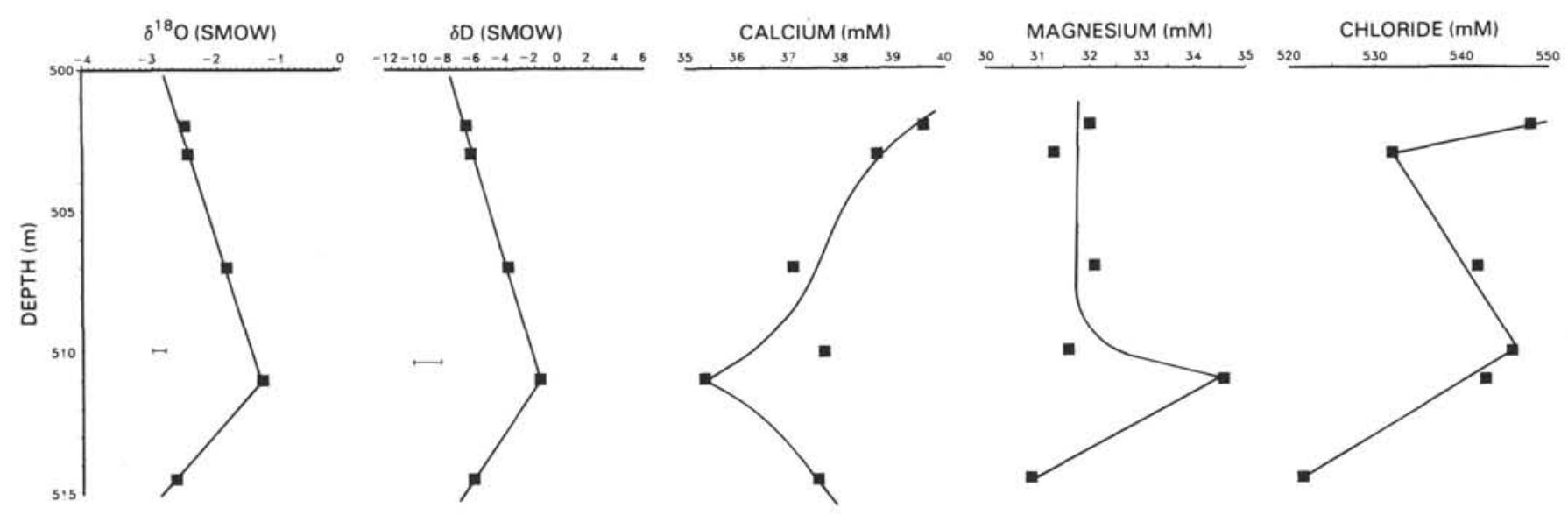

Figure 5. Pore water $\delta^{18} \mathrm{O}, \delta \mathrm{D}$, calcium, magnesium, and chloride profiles, Hole 671C. Curves through data are eye-drawn and subjective. Pore water chemical analysis of closely spaced samples indicates different chemical anomalies are not correlative. 

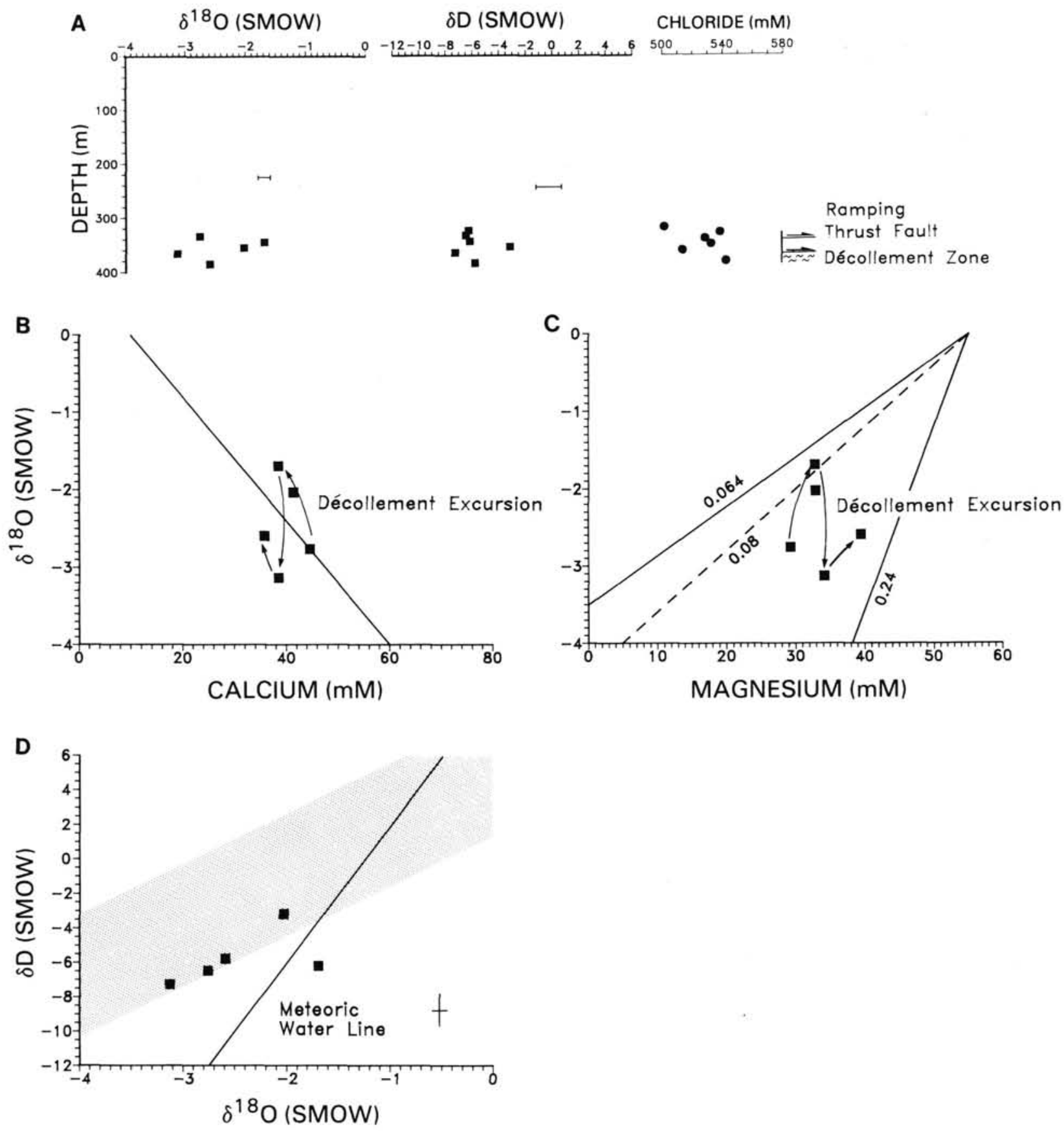

Figure 6. Isotopic results, Site 675. (A) Pore water $\delta^{18} \mathrm{O}$ and $\delta \mathrm{D}$ versus depth. (B) Correlation of pore water calcium concentrations with $\delta^{18} \mathrm{O}$ values. (C) Correlation of pore water magnesium concentrations with $\delta^{18} \mathrm{O}$ values. (D) Correlation of pore water oxygen and hydrogen isotope ratios. All conventions as at Site 672 (Fig. 3) and Site 671 (Fig. 4).

nificant offset from the isotopic patterns established in a tectonically undisturbed section. The only evidence that fluid flow along fault zones has perturbed isotopic profiles at Site 676 are the irregularities in the profiles of $\delta^{18} \mathrm{O}$ and $\delta \mathrm{D}$ (Fig. 7A), both of which correlate with the bulge in the chloride profile centered at 250 mbsf. Isotopic, chloride, and methane profiles at Sites 675 and 676 are less disturbed than those at Site 671, which is in accord with the observation that deformation fabrics increase in intensity from east to west (pp. 489-490 \& 511-513, Mascle, Moore et al., 1988).

\section{Mid-Accretionary Prism}

Further upslope along the accretionary prism, deformation becomes more intense. Slope deposits are cut by thrust faults. Early-formed low-angle scaly fabrics and thrust faults are rotated into steep orientations and are cut by second generation, low-angle, out-of-sequence thrust faults (pp. 316-318 \& 391396, Mascle, Moore et al., 1988); stratal disruption by faulting also becomes apparent. Large-scale overturned and small-scale isoclinal folds are also formed. Fault zones are still marked by 

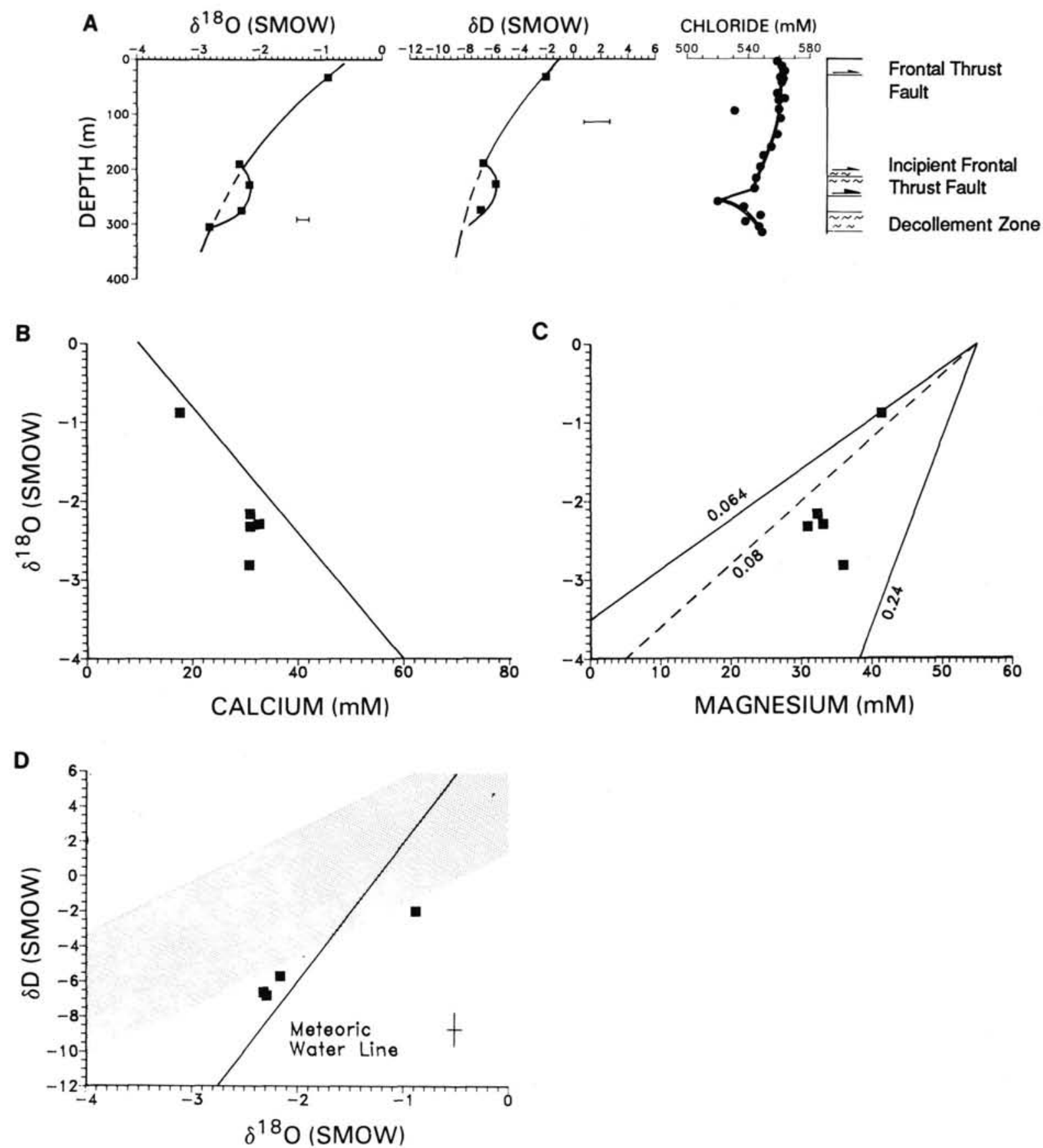

Figure 7. Isotopic results, Site 676. (A) Pore water $\delta^{18} \mathrm{O}$ and $\delta \mathrm{D}$ versus depth. (B) Correlation of pore water calcium concentrations with $\delta^{18} \mathrm{O}$ values. (C) Correlation of pore water magnesium concentrations with $\delta^{18} \mathrm{O}$ values. (D) Correlation of pore water oxygen and hydrogen isotope ratios. All conventions as at Site 672 (Fig. 3) and Site 671 (Fig. 4).

pore waters with low chlorinities, and at Site 674 fluid intrusion has caused a regional shift toward chloride concentrations as low as $2 / 3$ that of seawater values (pp. $329 \& 413$, Mascle, Moore et al., 1988). Methane is absent from pore waters, even though sulfate is locally exhausted.

\section{Site 674}

The most striking feature of the profiles of oxygen and hydrogen isotope ratios (Fig. 8A) is that there is much less scatter in the data compared with profiles from the deformation front, in spite of the much advanced structural complexity. $\delta^{18} \mathrm{O}$ values decrease regularly through the top part of the section at Site
674 , but then the trend reverses, and oxygen isotope ratios increase again. Although volcanic ash was observed less frequently at Site 674 (pp. 405-406, Mascle, Moore et al., 1988), pore waters with high $\delta^{18} \mathrm{O}$ values have at one stage been strongly affected by alteration reactions because diagenetic smectite, which is a byproduct of the alteration of ash, is common (Tribble, this volume), calcium concentrations of pore waters increase above seawater concentrations (Fig. 8B), and magnesium concentrations become very low (Fig. 8C). Moreover, calcium concentrations of pore waters have been lowered by incorporation of calcium into syntectonic calcite veins. Hence, high $\delta^{18} \mathrm{O}$ values reflect intrusion of ${ }^{18} \mathrm{O}$-rich fluid, either on a 

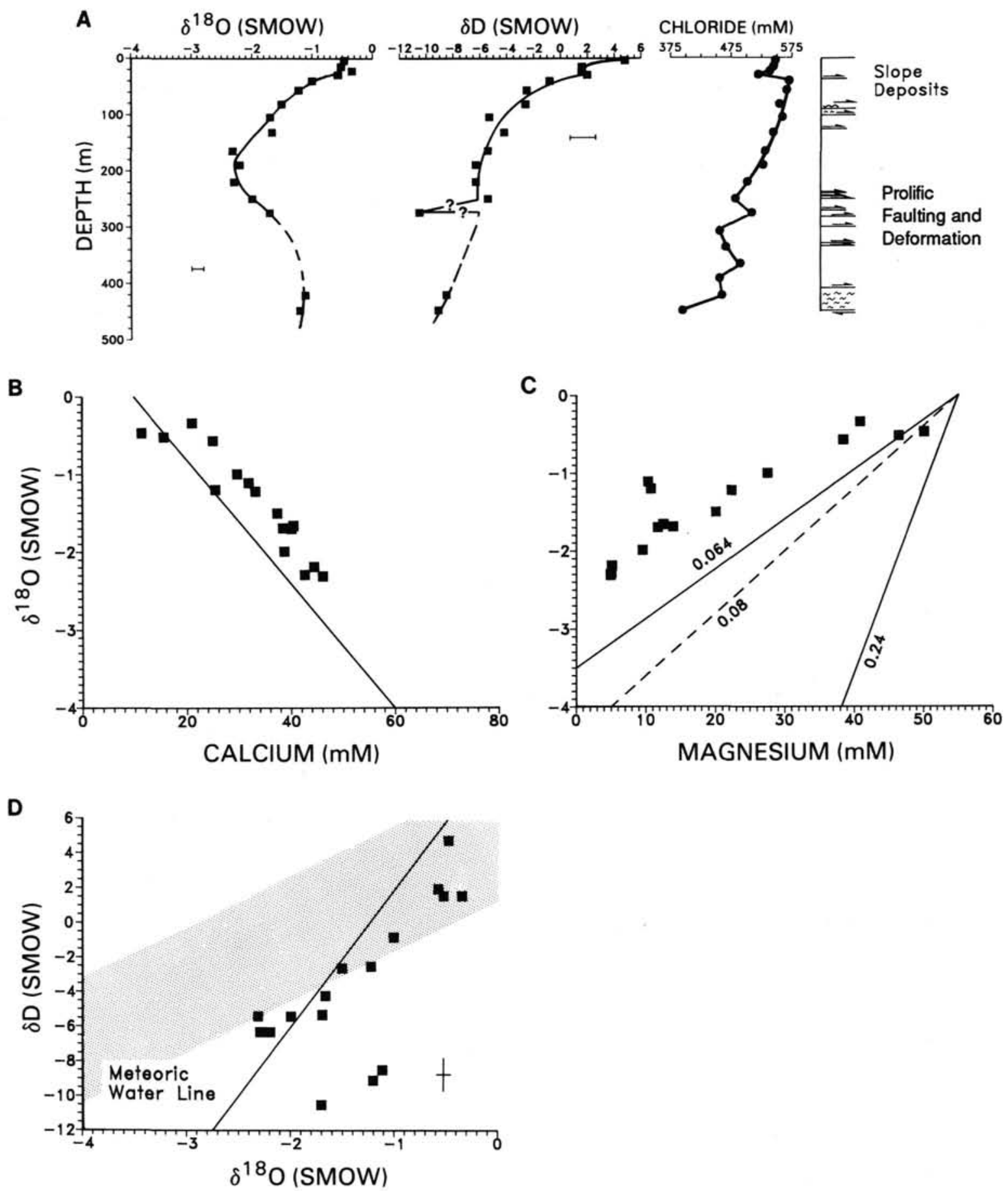

Figure 8. Isotopic results, Site 674. (A) Pore water $\delta^{18} \mathrm{O}$ and $\delta \mathrm{D}$ versus depth. (B) Correlation of pore water calcium concentrations with $\delta^{18} \mathrm{O}$ values. (C) Correlation of pore water magnesium concentrations with $\delta^{18} \mathrm{O}$ values. (D) Correlation of pore water oxygen and hydrogen isotope ratios. All conventions as at Site 672 (Fig. 3) and Site 671 (Fig. 4).

regionally pervasive scale, or on a local scale, but long enough ago that diffusion has smoothed small-scale variations in $\delta^{18} \mathrm{O}$ values.

An interesting footnote to these data is that $\Delta \delta^{18} \mathrm{O}: \Delta \mathrm{Mg}$ ratios of pore waters in Oligocene and Eocene sediments reflect no "basement signal" (high $\Delta \delta^{18} \mathrm{O}: \Delta \mathrm{Mg}$ ), in contrast to results from Site 671. We speculate that accretion of these sediments occurred long enough ago that intrusion of ${ }^{18} \mathrm{O}$-rich fluid and diffusion have erased the basement signal. Diffusion of material from the basement across the décollement zone must also be minor.

Deuterium is depleted at relatively shallow levels at Site 674, although the range of $\delta \mathrm{D}$ values is the same as at other sites. However, there is a shift in $\delta^{18} \mathrm{O}: \delta \mathrm{D}$ ratios toward higher $\delta^{18} \mathrm{O}$ values (Fig. 8D), suggesting that the ${ }^{18} \mathrm{O} /{ }^{16} \mathrm{O}$ composition of intruded fluid may be more distinct than the $\mathrm{D} / \mathrm{H}$ composition. 


\section{Site 673}

Sediments at Site 673 are also highly deformed, and the principal deformation features include a large overturned fold, numerous thrust faults, syntectonic carbonate veins, and pervasive scaly fabrics. Both oxygen and hydrogen isotope ratios change regularly with depth through the first $150 \mathrm{~m}$ of section, then remain constant to the bottom of the hole (Fig. 9A), although both ratios are lower than in pore waters in early Miocene sediments at Site 672. The homogeneous nature of the isotopic profiles and $\delta^{18} \mathrm{O}: \delta \mathrm{D}$ ratios (Fig. 9D) below $150 \mathrm{mbsf}$ suggests that if variations in $\delta^{18} \mathrm{O}$ and $\delta \mathrm{D}$ values existed, then they have been erased by diffusion.

Two samples have high $\Delta \delta^{18} \mathrm{O}: \Delta \mathrm{Mg}$ ratios relative to ratios established at Site 672 , and the deeper of these two samples (110-673B-12-2) is near a major thrust fault; however, no other

A $\quad \delta^{18} \mathrm{O}$ (SMOW)

$\delta \mathrm{D}(\mathrm{SMOW})$
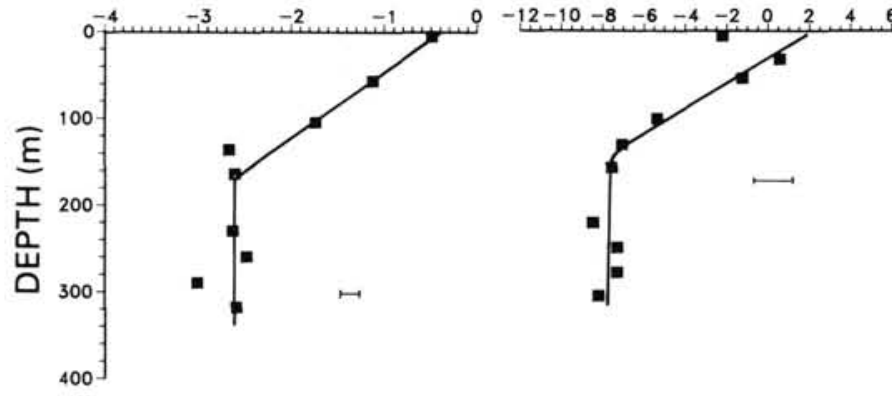

CHLORIDE ( $\mathrm{mM}$ )

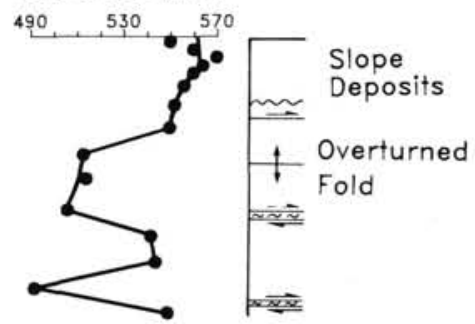

B
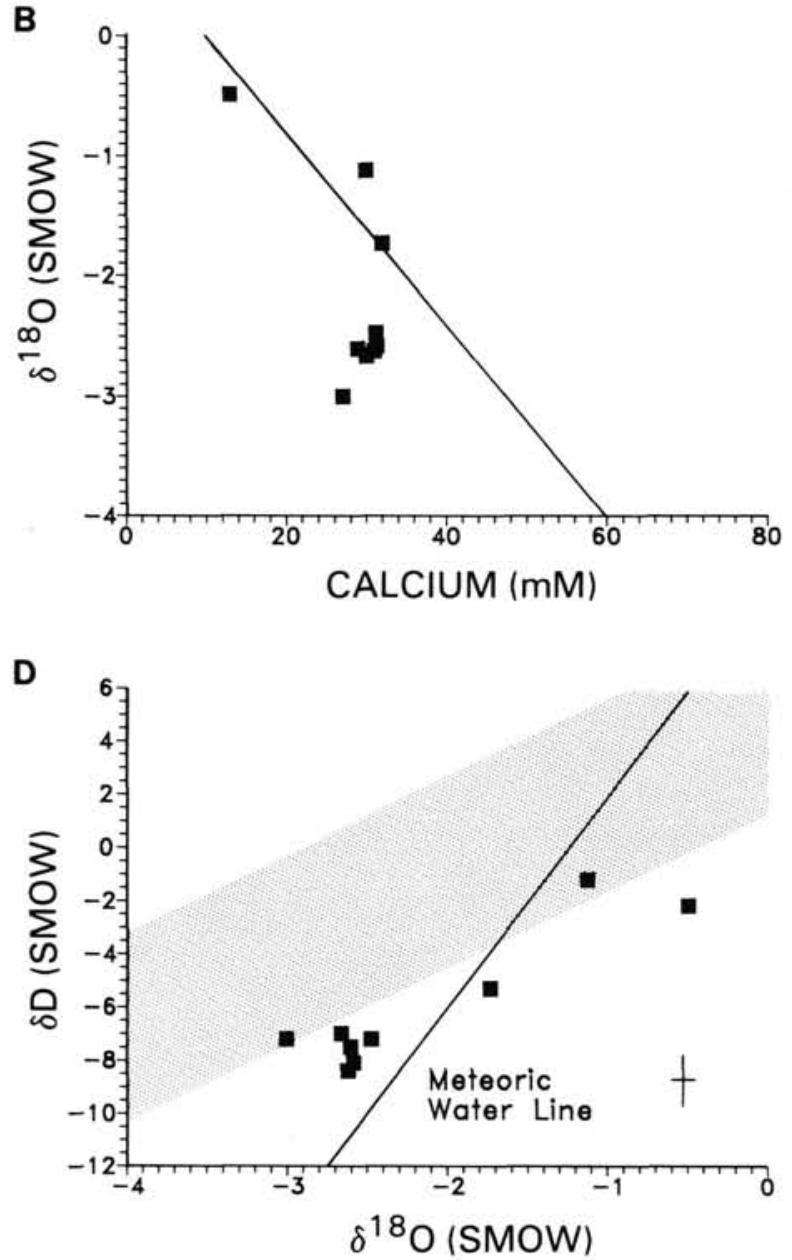

C

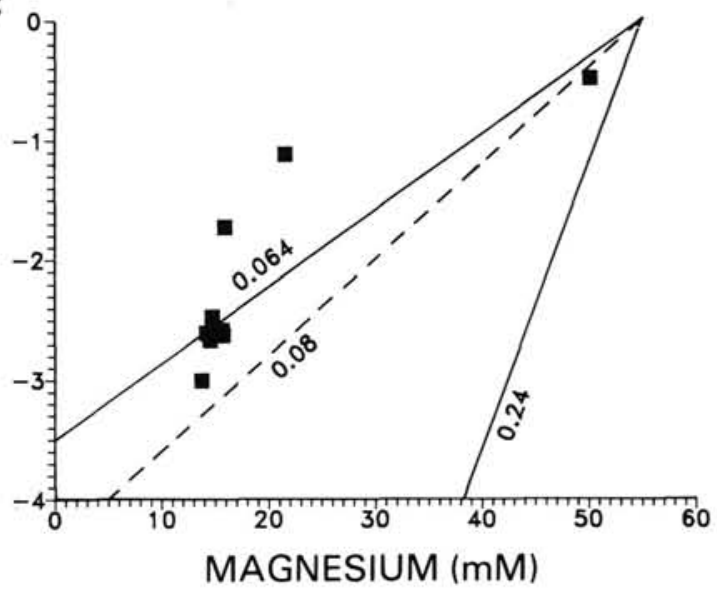

Figure 9. Isotopic results, Site 673. (A) Pore water $\delta^{18} \mathrm{O}$ and $\delta \mathrm{D}$ versus depth. (B) Correlation of pore water calcium concentrations with $\delta^{18} \mathrm{O}$ values. (C) Correlation of pore water magnesium concentrations with $\delta^{18} \mathrm{O}$ values. (D) Correlation of pore water oxygen and hydrogen isotope ratios. All conventions as at Site 672 (Fig. 3) and Site 671 (Fig. 4). 
chemical system is disturbed by this fault. Based on geochemical data from pore waters (Fig. 9B \& 9C; Gieskes et al., this volume), alteration of volcanic ash is again deemed a major diagenetic process, although mineralogical data are lacking. Intrusion of ${ }^{18} \mathrm{O}$-rich fluid along faults has caused high $\Delta \delta^{18} \mathrm{O}: \Delta \mathrm{Ca}$ and $\Delta \delta^{18} \mathrm{O}: \Delta \mathrm{Mg}$ ratios, notwithstanding the sink for calcium in syntectonic calcite veins.

Data from Sites 673 and 674 offer further constraints on the hydrogen isotope history of pore waters. If conversion of volcanic ash to smectite is the main influence on hydrogen isotope ratios of pore waters, then changes in calcium and magnesium concentrations should be related to changes in $\delta \mathrm{D}$ values. However, as mentioned earlier, the range of $\delta \mathrm{D}$ values remains constant across the accretionary prism, but changes in magnesium concentration are more than twice as great at Sites 673 and 674 than at Site 672, and changes in calcium concentrations are only $1 / 3$ to $1 / 2$ those at the reference site. Either other processes are responsible for the observed hydrogen isotope ratios in pore waters, or fractionation of hydrogen isotopes between pore waters and clay minerals is complicated by the fact that hydrogen may be incorporated into hydroxyl groups and interlayer sites.

\section{DISCUSSION OF ISOTOPIC RESULTS}

Oxygen isotope ratios of pore waters in the Northern Barbados accretionary prism have principally been affected by alteration of volcanic ash and basaltic ocean crust. Deformation processes have led to modification of isotopic profiles by rapidly burying sediments along thrust faults, thereby changing diffusive path lengths, and by creating fractures and faults that permit migration of fluid of unusual isotopic composition. Based on the isotopic data, the décollement zone appears to be the principal fluid conduit. Interpretation of hydrogen isotope ratios are confounded because $\mathrm{D} / \mathrm{H}$ fractionation processes in deep marine sediments are still too poorly understood to be useful. However, the pattern of hydrogen isotope ratio variation with depth indicates intrusion of an isotopically distinct fluid.

\section{Sources of Exotic Fluid}

Fluids that have been introduced into the accretionary prism along faults and fractures are enriched in ${ }^{18} \mathrm{O}$, depleted in chloride (fresher), and probably both enriched and depleted in deuterium. Evidence from Holes $671 \mathrm{~B}$ and $671 \mathrm{C}$ suggests that these geochemical characteristics may not always be present in a single water sample, leading to the hypothesis that several diagenetic processes may affect the geochemistry of exotic fluids (Fig. 10). In attempting to identify possible sources for the exotic fluids, the variations in ${ }^{18} \mathrm{O} /{ }^{16} \mathrm{O}$ and $\mathrm{D} / \mathrm{H}$ ratios and chloride concentrations must be combined with the fact that other major constituents (e.g., $\mathrm{Ca} \& \mathrm{Mg}$ ) remain unchanged (Gieskes et al., this volume). The processes that are most likely to be responsible for this group of changes include: smectite dewatering, clay membrane filtration, low-temperature mineral recrystallization, smectite recrystallization, and mineral dissolution.

\section{Smectite Dewatering}

Smectites contain water between aluminosilicate layers (e.g., Colten-Bradley, 1987) and although one or two layers may be retained until smectite is transformed to illite (Koster van Groos and Guggenheim, 1984; Koster van Groos and Guggenheim, 1987; Colten-Bradley, 1987), some interlayer water may be lost earlier in the diagenetic history of the sediment. Interlayer water may be less saline (Chilingarian et al., 1973; Rosenbaum, 1976) than sea water although experimental evidence is not fully convincing. The oxygen and hydrogen isotope composition of interlayer water is similarly controversial.

Much interlayer water probably exists as hydration sheaths around cations attracted to interlayer sites by charge imbalances caused by cationic substitution and structural defects in the TOT sandwich structure (e.g. Colten-Bradley, 1987). The composition of cations in interlayer sites strongly influences the potential oxygen isotopic fractionation between interlayer and bulk water because the presence of aluminum and magnesium in solutions causes large ${ }^{18} \mathrm{O} /{ }^{16} \mathrm{O}$ fractionation $(10001 \mathrm{n} \alpha$ hydration-bulk water $=25$ and $10 \%$, respectively; Taube, 1954; Sofer and Gat, 1972). The presence of singly charged cations, such as sodium, causes little or no isotopic fractionation. As ColtenBradley (1987) points out, smectites containing more than one water interlayer may contain divalent cations, suggesting that interlayer water may be enriched in ${ }^{18} \mathrm{O}$. Hydrogen isotopes similarly appear to be fractionated by creation of hydration sheaths around cations with deuterium preferentially incorporated into the hydration sphere (Stewart and Friedman, 1975).

In summary, it is plausible that interlayer water of clays is enriched in both ${ }^{18} \mathrm{O}$ and $\mathrm{D}$, although direct tests are lacking. Loss of interlayer water into pore spaces may enrich pore waters in both ${ }^{18} \mathrm{O}$ and $\mathrm{D}$. The degree of enrichment may depend on the amount of interlayer water expelled and the composition of cations in interlayer sites. Moreover, expulsion of interlayer water may be a fundamentally significant process in subduction zones where clay minerals are abundant; similar isotopic results from the Peru subduction zone have led workers to independently propose the same mechanism (Suess, von Huene et al., 1988). We suggest that loss of interlayer water from smectites may be an important process in generating fluids that subsequently migrate along faults.

\section{Membrane Filtration}

Slightly charged clay minerals may act as ionic filters causing ions to be retained in clays during water expulsion (Hanshaw and Coplen, 1973). However, membrane filtration causes the expelled, "fresher" fluids to be depleted in ${ }^{18} \mathrm{O}$ and deuterium while the residual, more saline fluid is enriched in ${ }^{18} \mathrm{O}$ and deuterium (Coplen and Hanshaw, 1973; Phillips and Bentley, 1987). These associations are opposite to the observed trends in expelled fluids and may be only important in changing chloride concentrations.

\section{Low-Temperature Mineral Recrystallization}

Recrystallization of minerals formed at temperatures lower than the recrystallization temperature will enrich pore waters in ${ }^{18} \mathrm{O}$ as mineral-water fractionations decrease with increasing temperature. Given the regional increase in pore water $\delta^{18} \mathrm{O}$ values observed at Sites 673 and 674, the dramatic increase in pore water $\delta^{18} \mathrm{O}$ values in the décollement zone ( $\left.>1 \% 0\right)$, and average porosities of $50 \%$ (Mascle, Moore et al., 1988), only smectite exists in sufficient abundance to produce this degree of isotopic change (Tribble, this volume).

\section{Smectite Recrystallization}

Transformation of smectite to illite has been proposed to occur either by solid-state (Hower et al., 1976) or dissolution-reprecipitation mechanisms (Boles and Franks, 1979). Only dissolution-reprecipitation reactions will modify the geochemistry of pore waters significantly so this mechanism is assumed here. Smectite formed at low temperatures will be strongly enriched in ${ }^{18} \mathrm{O}$ (Savin and Epstein, 1970), and release of large quantities of oxygen into the pore fluid during a smectite-illite reaction (e.g. Boles and Franks, 1979) will increase $\delta^{18} \mathrm{O}$ values of pore waters. This effect was observed by Yeh and Savin (1977) in a study of the oxygen isotope ratios of clay minerals in Gulf Coast sediments whereby an inferred increase in $\delta^{18} \mathrm{O}$ values of pore waters at temperatures between $55-90^{\circ} \mathrm{C}$ correlates with the observation of increasing proportions of illite in the sediment. Similarly, $\delta \mathrm{D}$ values of pore waters may also increase when smectite 


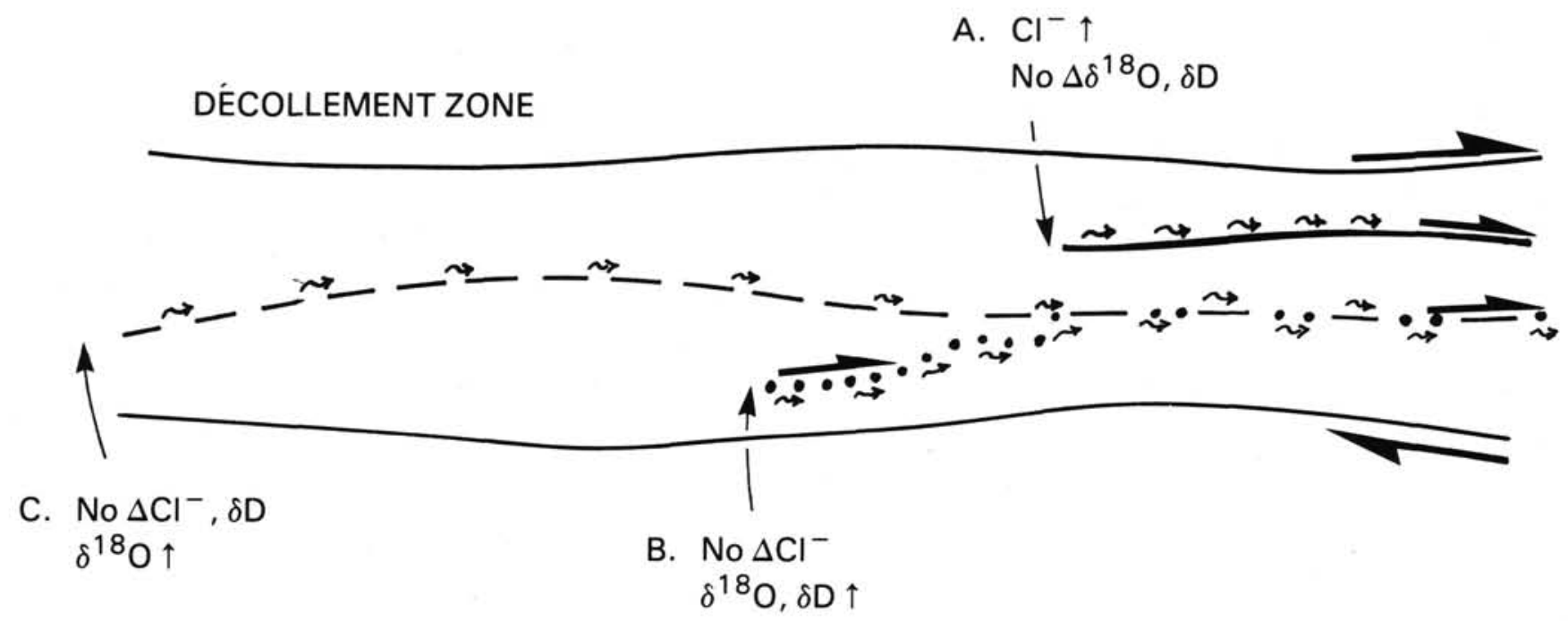

Figure 10. Interpretive history of faulting and fluid migration in the décollement zone. To create a complex vertical stacking of pore water geochemistries within décollement zone, individual faults must intersect and tap fluids of variable chemistry from different regions along the décollement zone. Deformation rapidly jumps from one fault to another within the décollement zone to allow preservation of different fluid flow episodes in close vertical proximity. Once fluid is tapped, it may or may not mix with other fluids during migration. Relatively shorttravelled fluids will remain unmixed most easily while far-travelled fluids will eventually mix. Determining quantitatively how far fluids migrate without mixing will provide clues to the distance of fluid movement during faulting episodes.

is transformed to illite (Yeh, 1980). Dissolution of smectite and precipitation of illite will consume potassium and release sodium, calcium, magnesium, iron, and silica (Reaction 2, Boles and Franks, 1979); chloride concentrations in pore waters may decrease if interlayer water is added to pore fluids.

If the smectite-illite transition is important in altering pore water $\delta^{18} \mathrm{O}$ values, then fluid travels from regions below the accretionary prism where temperatures are at least $50{ }^{\circ} \mathrm{C}$ (e.g., Boles and Franks, 1979). If methane within the décollement zone is truly thermogenic (see Appendix), then it is possible that fluids are affected by processes occurring much deeper beneath the accretionary prism. Analyses of clay mineralogy indicate the presence of mixed layer illite-smectites, interpreted by Tribble (this volume) as forming in situ at lower than expected temperatures; curiously, mixed layer clays beneath the décollement zone at Site 671 occur in association with pore waters that appear unaffected by smectite-illite reactions.

\section{Mineral Dissolution}

Minerals are mostly enriched in ${ }^{18} \mathrm{O}$ relative to waters so dissolution may increase $\delta^{18} \mathrm{O}$ values of waters. However, at low temperatures, silica and carbonate solubilities in water are low. Irreversible dissolution will not quantitatively change pore water $\delta^{18} \mathrm{O}$ values before a new mineral is precipitated which will then buffer any further fluid ${ }^{18} \mathrm{O}$ enrichment. An exception to this statement is the dissolution of methane hydrates, which causes large enrichments of ${ }^{18} \mathrm{O}$ and $\mathrm{D}$ in pore waters (Harrison et al., 1982; Jenden and Gieskes, 1983; Hesse et al., 1985). However, dissolution of hydrates is interpreted to be unimportant in the Leg 110 area because hydrates have not been detected on seismic reflection profiles, methane concentrations are too low (Mascle, Moore et al., 1988), and the extent of deuterium enrichment in pore waters is too small.

\section{Stable Isotope Data-Evidence for the Style of Deformation and Fluid Transport}

Analyses of $\delta^{18} \mathrm{O}$ and $\delta \mathrm{D}$ values of pore waters in the Barbados accretionary prism may help shed light on three aspects of the structural and hydrologic evolution, including: (1) the age of thrust faulting and associated fluid flow, (2) the deformation history of fault zones, (3) distances of fluid transport.

\section{Age of Faulting and Fluid Flow}

Heat diffuses faster than water (and constituent $\mathrm{O}$ - and $\mathrm{H}$ isotopes), which in turn diffuses more rapidly than major elements, and by mapping diffusion profiles of each of these groups, it should be possible to estimate the time elapsed between fluid flow along faults and fluid sampling. For example, at Site 673 (Fig. 9A), below 150 mbsf profiles of oxygen and hydrogen isotope ratios are smooth whereas the profile of chloride concentrations is ragged. If the fluid intrusion events that produced the low chlorinities were also associated with anomalous $\delta^{18} \mathrm{O}$ and $\delta \mathrm{D}$ values, then the time elapsed since fluid intrusion could be estimated to within a factor of ten (the difference in diffusion rates). Unfortunately, at this point it cannot be confidently determined that the intruded fluids were isotopically and chemically anomalous.

\section{Deformation Histories of Faults}

Understanding how fluids of different isotopic and geochemical composition mix during fluid migration may help distinguish continuously flowing fluid that has entrained fluid everywhere along its path from fluid migrating episodically and which only mixes with surrounding fluid between flow events. The apparent diversity in the geochemical character of fluids intruded along faults in this study, especially in Holes 671B and $671 \mathrm{C}$ (Fig. 10), suggests that episodic fluid flow may be important here.

\section{Fluid Transport Distances}

Analyses of stable isotope ratios of pore waters and methane (Appendix) suggests that there may be a far-traveled component of fluid sampled in the décollement zone, thereby widening the range of potential diagenetic reactions that may be influencing the geochemical composition of migrating fluids. Other geochemical tracers may further constrain transport distances.

\section{SUMMARY}

Deformation of sediment in the Northern Barbados accretionary prism has led to fluid and volume loss at deeper structural levels, resulting in fluid migration primarily along faults and fractures, especially the décollement zone. Fluids in fault 
zones are distinguished by ${ }^{18} \mathrm{O}$ enrichment relative to fluids in surrounding sediments and by their hydrogen isotope composition. Because the present understanding of processes that cause fractionation of hydrogen isotopes in marine sediments is poor, it is currently impossible to determine whether fluids in fault zones are enriched or depleted in deuterium. Thrusting of sediment packages has altered diffusion between sediment pores and the ocean and underlying basement, also resulting in the modification of the isotopic composition of pore waters. All of these changes are superposed on pore waters that have evolved as a result of low-temperature alteration of volcanic ash in the sediment and the underlying basaltic ocean crust.

Likely sources of ${ }^{18} \mathrm{O}$-rich fluid include dewatering of clay minerals by the collapse of smectite interlayers and smectite recrystallization to form illite. Smectite recrystallization is inferred to be occurring deep beneath the accretionary prism, but whether fluid from such deep levels comprises a large component of the fluid migrating along faults is speculative. The hypothesis that a component of the fluid in faults is deeply derived is supported by the tentative interpretation of carbon isotope ratio measurements of methane sampled from the décollement zone (Appendix). One important barrier to tagging the source of fluids is the strong suggestion that fluids sampled along faults may be mixtures of fluids that have been influenced by different diagenetic processes.

Further information about the history, age, and style of faulting in accretionary prisms may be gleaned from examination of profiles of oxygen and hydrogen isotope ratios in conjunction with those of major element concentrations and temperature. Closely spaced sampling around fault zones will help define diffusivities across faults and therefore elucidate the material properties of sediments therein.

\section{ACKNOWLEDGEMENTS}

We thank the crew and staff aboard the JOIDES Resolution for their support and help. Funding for the stable isotope analyses was provided by the United States Science Advisory Committee, and data analysis and manuscript preparation were supported by an NSF/NATO postdoctoral fellowship to Vrolijk at the University of Cambridge. Matthew Stairs and Nicholas Vrolijk assisted in making isotopic analyses. We especially appreciate the help of Bill Carothers with the gas chromatograph separations. Marge Golan-Bac and Keith Kvenvolden offered advice and help with the headspace extractions, and Jim Dolan kindly sampled sediments for methane gas at Site 676. Discussions with Harry Elderfield proved invaluable, as did reviews by Erwin Suess, Paul Baker, Keith Kvenvolden, and Max Coleman.

\section{REFERENCES}

Barron, J., Larsen, B., Baldauf, J. G., Alibert, C., Berkowitz, S. P., Caulet, J. P., Chambers, S. R., Cooper, A. K., Cranston, R., Dorn, W. U., Ehrmann, W. U., Fox, R., Fryxell, G., Hambrey, M. J., Huber, B. T., Jenkins, C. J., Kang, S. H., Keating, B., Mehl, K. W., Noh, I., Ollier, G., Pettenger, A., Sakai, H., Schroder, C. J., Solheim, A., Stockwell, D., Thierstein, H., Tocher, B., Turner, B., and Wei, W., 1988. Early glaciation of Antarctica. Nature, 333:303304.

Boles, J. R., and Franks, S. G., 1979. Clay diagenesis in Wilcox sandstones of southwest Texas: implications of smectite diagenesis on sandstone cementation. J. Sed. Petrol., 49:55-70.

Boulegue, J., Benedetti, E. L., Dron, D., Mariotti, A., and Letolle, R., 1987. Geochemical and biogeochemical observations on the biological communities associated with fluid venting in Nankai Trough and Japan Trench subduction zones. Earth Planet. Sci. Lett., 83:343355.

Cerling, T. E., Brown, F. H., and Bowman, J. R., 1985. Low-temperature alteration of volcanic glass: hydration, $\mathrm{Na}, \mathrm{K},{ }^{18} \mathrm{O}$ and $\mathrm{Ar}$ mobility. Chem. Geol., 52:281-293.

Chilingarian, G. V., Sawabini, C. T., and Rieke, H. H., 1973. Effect of compaction on chemistry of solutions expelled from montmorillonite clay saturated in sea water. Sedimentol., 20:391-398.
Coleman, M. L., Shepherd, T. J., Durham, J. J., Rouse, J. E., Moore, G. R., 1982. Reduction of water with zinc for hydrogen isotope analysis. An. Chem., 54:993-995.

Colten-Bradley, V. A., 1987. Role of pressure in smectite dehydration Effects on geopressure and smectite-to-illite transformation. $\mathrm{Am}$. Assoc. Pet. Geol. Bull., 71:1414-1427.

Coplen, T. B., and Hanshaw, B. B., 1973. Ultrafiltration by a compacted clay membrane-I. Oxygen and hydrogen isotopic fractionation. Geochim. Cosmochim. Acta, 37:2295-2310.

Davis, D. M., and Hussong, D. M., 1984. Geothermal observations during DSDP Leg 78A. In Biju-Duval, B., and Moore, J. C., et al., Init. Repts. DSDP, 78A: Washington (U. S. Govt. Printing Office), 593-598.

England, P. C., and Thompson, A. B., 1984. Pressure-temperature-time paths of regional metamorphism. Part I. Heat transfer during evolution of regions of thickened continental crust. J. Petrol., 25:894298.

Epstein, S., Mayeda, T., 1953. Variation of $\mathrm{O}^{18}$ content of waters from natural sources. Geochim. Cosmochim. Acta, 4:213-224.

Friedman, I., 1953. Deuterium content of natural waters and other substances. Geochim. Cosmochim. Acta, 4:89-103.

Gieskes, J. M., and Lawrence, J. R., 1981. Alteration of volcanic matter in deep sea sediments: evidence from the chemical composition of interstitial waters from deep sea drilling cores. Geochim. Cosmochim. Acta, 45:1687-1703.

Gieskes, J. M., Elderfield, H., Lawrence, J. R., and LaKind, J., 1984. Interstitial Water Studies Leg 78A. In Biju-Duval, B., and Moore, J. C., et al., Init. Repts. DSDP, 78A: Washington (U. S. Govt. Printing Office), 377-384.

Gieskes, J. M., Lawrence, J. R., Perry, E. A., Grady, S. J., Elderfield, H., 1987. Chemistry of interstitial waters and sediments in the Norwegian-Greenland Sea, Deep Sea Drilling Project Leg 38. Chem. Geol., 63:143-155.

Gieskes, J., Blanc, G., Vrolijk, P., Moore, J. C., Mascle, A., Taylor, E., Andreiff, P., Alvarez, F., Barnes, R., Beck, C., Behrmann, J., Brown, K., Clark, M., Dolan, J., Fisher, A., Hounslow, M., McLellan, P., Moran, K., Ogawa, Y., Sakai, T., Schoonmaker, J., Wilkens, R., Williams, C., 1989. Hydrogeochemistry in the Barbados Accretionary Complex: Leg 110 ODP. Paleogeog., Paleoclimatol., Paleoecol., 71:83-96.

Gunter, B. D., and Gleason, J. D., 1971. Isotope fractionation during gas chromatographic separations. J. Chrom. Sci., 9:191-192.

Hanshaw, B.B., and Coplen, T.B., 1973. Ultrafiltration by compacted clay membrane-II: Sodium ion exchange at various ionic strengths. Geochim. Cosmochim. Acta, 37:2311-2327.

Harrison, W. E., Hesse, R., and Gieskes, J. M., 1982. Relationship between sedimentary facies and interstitial water chemistry of slope, trench, and Cocos plate sites from the Middle America trench transect, active margin off Guatemala, Deep Sea Drilling Project Leg 67. In: Aubouin, J., von Huene, R., et al., Init. Repts. DSDP, 67: Washington (U. S. Govt. Printing Office), 603-614.

Hesse, R., Lebel, J., and Gieskes, J. M., 1985. Interstitial water chemistry of gas-hydrate-bearing sections on the Middle America trench slope, Deep-Sea Drilling Project Leg 84. In: von Huene, R., Aubouin, J., et al., Init. Rpts. DSDP, 84: Washington (U. S. Government Printing Office), 727-737.

Hower, J., Eslinger, E. V., Hower, M. E., and Perry, E. A., 1976. Mechanism of burial metamorphism of argillaceous sediments: 1 . Mineralogical and chemical evidence. Geol. Soc. Am. Bull., 87:725-737.

Jenden, P. D., and Gieskes, J. M., 1983. Chemical and isotopic composition of interstitial water from Deep Sea Drilling Project Sites 533 and 534. In: Sheridan, R. E., Gradstein, F. M., et al., Init. Rpts. $D S D P$, 76: Washington (U. S. Govt. Printing Office), 453-461.

Knauth, L. P., and Epstein, S., 1976. Hydrogen and oxygen isotope ratios in nodular and bedded cherts. Geochim. Cosmochim. Acta, 40: $1095-1108$.

Koster van Groos, A. F., and Guggenheim, S., 1984. The effect of pressure on the dehydration reaction of interlayer water in Na-montmorillonite (SWy-1). Am. Mineral., 69:872-879.

1987. Dehydration of a Ca- and a Mg-exchanged montmorillonite (SWy-1) at elevated pressures. Am. Mineral., 72:292-298.

Kulm, L. D., Suess, E., Moore, J. C., Carson, B., Lewis, B. T., Ritger, S. D., Kadko, D. C., Thornberg, T. M., Embley, R. W., Rugh, W. D., Massoth, G. J., Langseth, M. G., Cochran, G. R., and Scam- 
man, R. L., 1986. Oregon subduction zone: venting, fauna, and carbonates. Science, 231:561-566.

Kvenvolden, K. A., and Redden, G. D., 1980. Hydrocarbon gas in sediment from the shelf, slope, and basin of the Bering Sea. Geochim. Cosmochim. Acta, 44:1145-1150.

Lawrence, J. R., and Gieskes, J. M., 1981. Constraints on water transport and alteration in the oceanic crust from the isotopic composition of pore water. J. Geophys. Res., 86:7924-7934.

Lawrence, J. R., and Taviani, M., 1988. Extreme hydrogen, oxygen and carbon isotope anomalies in the pore waters and carbonates of the sediments and basalts from the Norwegian Sea: Methane and hydrogen from the mantle?. Geochim. Cosmochim. Acta, 52:2077-2083.

Lawrence, J. R., Gieskes, J. M., and Broecker, W. S., 1975. Oxygen isotope and cation composition of DSDP pore waters and the alteration of layer II basalts. Earth Plan. Sci. Lett., 27:1-10.

Lawrence, J. R., Drever, J. I., Anderson, T. F., and Brueckner, H. K., 1979. Importance of alteration of volcanic material in the sediments of Deep Sea Drilling Site 323: chemistry, ${ }^{18} \mathrm{O} /{ }^{16} \mathrm{O}$, and ${ }^{87} \mathrm{Sr} /{ }^{86} \mathrm{Sr}$. Geochim. Cosmochim. Acta, 43:573-588.

Liu, K. L. and Epstein, S., 1984. The hydrogen isotope fractionation between kaolinite and water. Isot. Geochem., 2:335-350.

Manheim, F. T., and Sayles, F. L., 1974. Composition and origin of interstitial waters of marine sediments, based on deep sea drill cores. In Goldberg, E. D. (Ed.), The Sea, 5, Marine Chemistry, New York, (Wiley): 527-568.

Mascle, A., Moore, J. C., et al., 1988. Proc. ODP, Init. Repts. (Part A), 110. College Station, TX (Ocean Drilling Program).

McDuff, R. E., 1981. Major cation gradients in DSDP interstitial waters: the role of diffusive exchange between seawater and upper oceanic crust. Geochim. Cosmochim. Acta, 45:1705-1713.

1985. The chemistry of interstitial waters, Deep Sea Drilling Project Leg 86. In Heath, G. R., Burckle, L. H., et al., Init. Repts. DSDP, 86: Washington (U. S. Govt. Printing Office): 675-687.

Moore, J. C., Mascle, A., Taylor, E., Andreieff, P., Alvarez, F., Barnes, R., Beck, C., Behrmann, J., Blanc, G., Brown, K., Clark, M., Dolan, J., Fisher, A., Gieskes, J., Hounslow, M., McLellan, P., Moran, K., Ogawa, Y., Sakai, T., Schoonmaker, J., Vrolijk, P., Wilkens, R., Williams, R., 1988. Tectonics and hydrogeology of the northern Barbados Ridge: Results from Ocean Drilling Program Leg 110. Geol. Soc. Am. Bull., 100:1578-1593.

1987. Expulsion of fluids from depth along a subductionzone decollement horizon. Nature, 326:785-788.

Muehlenbachs, K., 1986. Alteration of the ocean crust and the ${ }^{18} \mathrm{O}$ history of seawater. In Valley, J. W., Taylor, H. P., Jr., and O'Neil, J. R. (Eds.) Stable isotopes in high temperature geological processes, $R e$ views in Mineralogy, 16:425-444.

Perry, E. A., Jr., Gieskes, J. M., and Lawrence, J. R., 1976. Mg, Ca, and $\mathrm{O}^{18} / \mathrm{O}^{16}$ exchange in the sediment-pore water system, Hole 149 , DSDP. Geochim. Cosmochim. Acta, 40:413-423.

Phillips, F. M., and Bentley, H. W., 1987. Isotopic fractionation during ion filtration: I. Theory. Geochim. Cosmochim. Acta, 51:683-695.

Roether, W., 1970. Water- $\mathrm{CO}_{2}$ exchange set-up for the routine ${ }^{18}$ Oxygen assay of natural waters. Inter, J. Appl. Rad. Isot., 21:379-387.

Rosenbaum, M. S., 1976. Effect of compaction on the pore fluid chemistry of montmorillonite. Clays Clay Min., 24:118-121.

Savin, S. M., and Epstein, S., 1970. The oxygen and hydrogen isotope geochemistry of clay minerals. Geochim. Cosmochim. Acta, 34:2542.

Schoell, M., 1980. The hydrogen and carbon isotopic composition of methane from natural gases of various sources. Geochim. Cosmochim. Acta, 44:649-661.

Sofer, Z., and Gat, J. R., 1972. Activities and concentrations of oxygen18 in concentrated aqueous salt solutions: analytical and geophysical implications. Earth Plan. Sci. Lett., 15:232-238.

Stewart, M. K., and Friedman, I., 1975. Deuterium fractionation between aqueous salt solutions and water vapor. J. Geophys. Res., 80: 3812-3818.

Suess, E., von Huene, R., Emeis, K. C., Bourgois, J., Cruzado Castaneda, J. C., DeWever, P., Eglinton, G., Fernandex, A. W. S., Garrison, R., Greenberg, M., Hill, P., Ibaraki, M., Kastner, M., Kemp, A. E. S., Kvenvolden K., Langridge, R., Lindsley-Griffin, N., McCabe, R., Marsters, J., Martini, E., Ocola, L., Paz, E. H., Resig, J., Schrader, H., Thornburg, T. M., Yamano, M., 1988. Ocean Drilling Program Leg 112, Peru continental margin: Part 2, Sedimentary his- tory and diagenesis in a coastal upwelling environment. Geology, 16: 939-943.

Suzuoki, T., and Epstein, S., 1976. Hydrogen isotope fractionation between $\mathrm{OH}$-bearing minerals and water. Geochim. Cosmochim. Acta, 40:1229-1240.

Taube, H., 1954. Use of oxygen isotope effects in the study of hydration of ions. J. Phys. Chem., 58:523-528.

Vrolijk, P. J., 1987. Paleohydrogeology and fluid evolution of the Kodiak accretionary complex, Alaska [PhD dissert.]. Univ. California, Santa Cruz.

Vrolijk, P., Myers, G., and Moore, J. C., 1988. Warm fluid migration along tectonic melanges in the Kodiak accretionary complex, Alaska. J. Geophys. Res., 93:10,313-10,324.

Wang, J. H., Robinson, C. V., and Edelman, I. S., 1953. Self-diffusion and structure of liquid water. III. Measurement of the self-diffusion of liquid water with $\mathrm{H}^{2}, \mathrm{H}^{3}$, and $\mathrm{O}^{18}$ as tracers. J. Am. Chem. Soc., 75:466-470.

Yeh, H. W., 1980. D/H ratios and late-stage dehydration of shales during burial. Geochim. Cosmochim. Acta, 44:341-352.

Yeh, H. W., and Savin, S. M., 1977. Mechanism of burial metamorphism of argillaceous sediments: 3. O-isotope evidence. Geol. Soc. Am. Bull., 88:1321-1330.

Date of initial receipt: 10 June 1988

Date of acceptance: 26 January 1989

Ms 110B-137

\section{APPENDIX \\ CARBON ISOTOPE RATIOS OF DISSOLVED METHANE GASES}

Mud from the décollement zone was sampled at two sites for shorebased analysis of carbon isotope ratios of methane. However, several difficulties in the sampling and analytical procedure have diminished the reliability of the data. These data and a detailed account of the method by which they were obtained are presented here in order to stress the limit to which the reported data may be interpreted.

\section{Sampling Procedure}

Head-space gas samples were taken according to procedures modified from Kvenvolden and Redden (1980). Departures from this technique include the fact that whole-round core samples could not be taken under the sample request protocol in effect during the cruise. Rather, samples were taken after the core had been cut into sections, although splitting of a single section was allowed immediately after the core had been brought into the laboratory. A sediment sample from half of the working section was immediately removed and placed into pint-sized cans. Helium-degassed seawater and $\mathrm{HgCl}_{2}$ were placed into the can with the sediment, and the can was subsequently sealed. The major difficulty with this part of the procedure was that as much as $10-20$ minutes elapsed before the sample was finally sealed. Also, each sediment sample had a large surface area. Both factors may have promoted loss of methane from the samples. The air in the head-space of each sample can was not purged with helium gas following sample sealing, as recommended by Kvenvolden and Redden (1980), which led to problems during subsequent sample treatment (see below). This departure from standard procedure came about because at the time of Leg 110, rigid sampling procedures by ODP and uncertainties about the best sampling techniques prevented the on-board sampling of the most undisturbed samples for isotopic analysis.

\section{Methane Purification and Conversion to $\mathrm{CO}_{2}$}

Mass spectrometric analysis of the carbon isotope composition of methane is accomplished by quantitative conversion of $\mathrm{CH}_{4}$ to $\mathrm{CO}_{2}$ at $800^{\circ} \mathrm{C}$ in a $\mathrm{CuO}$ furnace. However, because the headspace sample contained large quantities of air as well as methane, the conversion was hindered. To overcome this problem, methane was separated from air by passing the gas sample through a Perkin-Elmer Sigma 2000 gas chromatograph with a Porapak type Q-packed column at $8^{\circ} \mathrm{C}$. Gases emitted between ca. 4-7 minutes were collected as methane samples; passage of methane through the gas chromatographic column was monitered by the signal received from a hot wire detector. Methane was then trapped on a silica gel cooled to liquid nitrogen temperatures, and the helium carrier gas from the gas chromatograph was pumped away. Finally, methane oxidation produced $\mathrm{CO}_{2}$ which was analyzed by the mass spec- 
trometer. Results are reported in standard $\delta$ notation in \%o relative to the PeeDee Belemnite (PDB) standard.

Accuracy of the methane/air separation and subsequent methane oxidation procedure was evaluated by preparing a sample of air with methane of known isotopic composition in proportions similar to those of the unknown samples. This "standard" sample was then subjected to the same procedure described above.

\section{Isotopic Results}

The quantity of methane gas in any one headspace sample was too small for mass spectrometric analysis (Table 2). This problem arose because of the low concentrations of methane in the samples, and because the gas chromatographic separation process required discarding approximately $40 \%$ of each sample (N. B. Each sample was split before introduction into the gas chromatograph and no isotopic fractionation was therefore produced). To obtain a $\mathrm{CO}_{2}$ sample large enough for mass spectrometric analysis, individual samples were combined to produce two macro-samples (Table 2).

Macrosample \#1 consists of two samples taken from the décollement horizon. Sample 110-671D was obtained from a core during an abortive attempt to deploy the packer in the décollement zone after Site 675 was drilled; this core was never logged in the ODP core archive (pp. 72-73, Mascle, Moore et al., 1988). The recovered core contained abundant

Table 2. Carbon isotope composition of methane.

\begin{tabular}{lcccc}
\hline \multicolumn{1}{c}{ Sample number } & $\begin{array}{c}\text { Depth } \\
(\mathrm{mbs})\end{array}$ & $\begin{array}{c}\text { Sediment } \\
\text { volume } \\
\left(\mathrm{cm}^{3}\right)\end{array}$ & $\begin{array}{c}\text { Gas } \\
\text { volume } \\
(\mu \mathrm{mol})\end{array}$ & $\begin{array}{c}\delta^{13} \mathrm{C} \\
(\% 0)\end{array}$ \\
\hline Macrosample 1 & & & & \\
110-671D & 452 & ca. 150 & 3 & -22.6 \\
110-675A-8-6; $94-102 \mathrm{~cm}$ & 388 & 50 & 1 & \\
Macrosample 2 & & & & \\
110-676A-32-3; $39-53 \mathrm{~cm}$ & 295 & 100 & 2 & -32.4 \\
$110-676 \mathrm{~A}-30-5 ; 90-104 \mathrm{~cm}$ & 279 & 100 & & \\
$-31-4 ; 12-26 \mathrm{~cm}$ & 286 & 100 & 4.5 & \\
$-33-5 ; 90-104 \mathrm{~cm}$ & 308 & 100 & & \\
\hline
\end{tabular}

scaly green mudstone but lacked the characteristic reddish-orange radiolarian-rich mudstone of the décollement horizon. Although a large mud sample was obtained from this core, it was sampled long after drilling because the core barrel became stuck in the drill string and remained there throughout the packer experiment. Once the drill string was retrieved with the stuck core barrel, several hours elapsed before the core was finally freed and sampled. Sample 110-671D may have lost some methane. Sample 110-675A-8X-6, 94-102 cm was similarly taken from the décollement zone, but below the level of the largest chloride and methane anomalies (pp. 493-494, Mascle, Moore et al., 1988).

Macrosample \#2 was made from four samples from Site 676 along what appears to be the seaward propagation of the décollement zone. This interval contains the lithologically distinct orangish-brown radiolarian mudstone charactertic of the décollement horizon at Site 671 (p. 515, Mascle, Moore et al., 1988). Small chloride and methane anomalies were reported in Core 110-676A-31 (pp. 523 \& 526, Mascle, Moore et al., 1988), which suggests that fluid flow has occurred at this level.

The $\delta^{13} \mathrm{C}$ values of methane in the two macrosamples are -23 and $-32 \%$, respectively (Table 2 ). The relatively similar values between these two samples is encouraging, given the numerous opportunities for disruption of the samples. Analysis of a standard methane sample prepared in the same manner as the sample gases was offset by $+11.8 \%$ and suggests that the true isotopic ratios of the measured gases may be similarly offset. The source of the discrepancy may stem from contamination by a small amount of methane in the chromatographic column, although the column was periodically heated during sample analysis to drive off any adsorbed gases, or from incomplete collection of the sample. Errors resulting from gas chromatograph-induced fractionation would likely cause the measured carbon isotopic ratios to increase (Gunter and Gleason, 1971); for example if only the first $50 \%$ of the gas sample was collected from the gas chromatograph, then ${ }^{13} \mathrm{C} /{ }^{12} \mathrm{C}$ ratios would be $5 \%$ less. Therefore the carbon isotopic ratio of the first macrosample may actually be between -37 to $-42 \%$, while the second macrosample may be between -47 to $-52 \%$.

\section{Implications of Isotopic Results}

Methane with a $\delta^{13} \mathrm{C}$ value of -40 to $-50 \%$ is generally produced by thermal cracking of organic matter (Schoell, 1980). However, because of the great potential for sample contamination, this interpretation must remain tentative. In support of this interpretation is the fact that sulfate is found in samples with methane, suggesting that methane is not produced in situ. 